NBER WORKING PAPER SERIES

\title{
THE MORE THE MERRIER? THE EFFECT OF FAMILY COMPOSITION ON CHILDREN'S EDUCATION
}

\author{
Sandra E. Black \\ Paul J. Devereux \\ Kjell G. Salvanes \\ Working Paper 10720 \\ http://www.nber.org/papers/w10720
NATIONAL BUREAU OF ECONOMIC RESEARCH
1050 Massachusetts Avenue
Cambridge, MA 02138 \\ August 2004
}

We thank Daron Acemoglu, Janet Currie, Mary Daly, and participants at the Society of Labor Economists 2004 Annual Meetings, the Federal Reserve Bank of San Francisco, and the 2004 IRP Summer Institute for helpful comments. The views expressed herein are those of the author(s) and not necessarily those of the National Bureau of Economic Research.

(C2004 by Sandra E. Black, Paul J. Devereux, and Kjell G. Salvanes. All rights reserved. Short sections of text, not to exceed two paragraphs, may be quoted without explicit permission provided that full credit, including $(\mathrm{C}$ notice, is given to the source. 
The More the Merrier? The Effect of Family Composition on Children's Education Sandra E. Black, Paul J. Devereux, and Kjell G. Salvanes

NBER Working Paper No. 10720

August 2004

JEL No. I2, J1

\begin{abstract}
Among the perceived inputs in the "production" of child quality is family size; there is an extensive theoretical literature that postulates a tradeoff between child quantity and quality within a family. However, there is little causal evidence that speaks to this theory. Our analysis is able to overcome many limitations of the previous literature by using a rich dataset that contains information on the entire population of Norway over an extended period of time and allows us to match adult children to their parents and siblings. In addition, we use exogenous variation in family size induced by the birth of twins to isolate causation. Like most previous studies, we find a negative correlation between family size and children's educational attainment. However, when we include indicators for birth order, the effect of family size becomes negligible. This finding is robust to the use of twin births as an instrument for family size. In addition, we find that birth order has a significant and large effect on children's education; children born later in the family obtain less education. These findings suggest the need to revisit economic models of fertility and child "production", focusing not only on differences across families but differences within families as well.
\end{abstract}

Sandra E. Black

Department of Economics

UCLA

9373 Bunche Hall

Los Angeles, CA 90095-1477

and NBER

sblack@econ.ucla.edu
Paul G. Devereux

Department of Economics

UCLA

devereux@econ.ucla.edu
Kjell G. Salvanes

Department of Economics

Norwegian School of

Economics

kjell.salvanes@nhh.no 


\section{Introduction}

Economists have long been interested in understanding the factors that determine child outcomes. However, despite years of research, evidence on the components of the "production function" for children is still quite limited. Family environment is widely believed to be a primary component, but it is difficult to parcel this out into specific characteristics.

Among the perceived inputs in the production of child quality is family size. There is an extensive theoretical literature on the tradeoff between child quantity and quality within a family. The models date back to Becker (1960), who was motivated to explain the empirical regularity that families with higher income have fewer children. He theorized that, as income rises, individuals may choose to increase the average quality and reduce quantity. While the correlation between income and family size is clear, there is little further evidence that speaks to this theory.

A key element of the model is an interaction between quantity and quality in the budget constraint that leads to rising marginal costs of quality with respect to family size; this generates a tradeoff between quality and quantity. But is this tradeoff real? In particular, is it true that having a larger family has a causal effect on the "quality" of the children? Or is it the case that families who choose to have more children are (inherently) different, and the children would have done worse regardless of family size?

This paper attempts to isolate the causal effect of family size on children's outcomes by using data on the entire population of Norway and looking at the effect of an exogenous increase in the size of a family on children's educational attainment. Our dataset covers an extended period of time and allows us to match adult children to their 
parents and siblings; as a result, we are able to overcome many limitations of earlier research resulting from small sample sizes or limited information on children's outcomes after the children have left home. In addition, we have plausibly exogenous variation in family size (induced by the birth of twins) to isolate the true causal effect.

Like most previous studies, we find a negative correlation between family size and children's educational attainment. However, when we include indicators for birth order, the effects of family size are reduced to almost zero. These results are robust to a number of specifications, including the use of twins as an instrumental variable for family size. The evidence suggests that family size itself has little impact on the quality of each child but more likely impacts only the marginal children through the effect of birth order.

Given that birth order effects appear to drive the observed negative relationship between family size and child outcomes, we next turn our attention to birth order. Previously, these effects have proven very difficult to estimate credibly due to rigorous data requirements (Blake, 1989). Our unique dataset allows us to overcome these data problems and, unlike the previous literature, we utilize family fixed effects models to deal with unobserved family-level heterogeneity. We find evidence that birth order effects are strong, regardless of our estimation strategy. Moreover, the effects appear to be of similar magnitude across families of different sizes.

The evidence suggests that correlations of family size with educational attainment are driven by birth order effects; once birth order is controlled for, there is little if any causal effect of family size on educational attainment. The implications of these findings are quite different from the causal effect of family size on child quality implied by the 
simple quality/quantity model and may suggest a reconsideration of the determinants of child outcomes.

While our results speak directly to the nature of quantity/quality tradeoffs, they are also relevant to other questions. Family sizes continue to decline in developed countries and it has been suggested that this should be of benefit to children. Our results imply that, though average child outcomes may improve, there may be little effect on first-born children.

The paper unfolds as follows. Section 2 lays out the quantity/quality model and describes the empirical literature on the effects of family size. Section 3 describes our data. Section 4 presents our methodology and results. Section 5 turns to a more detailed investigation of birth order effects. Section 6 presents family size and birth order estimates for various subgroups of the sample. Section 7 presents some speculative evidence on the determinants of birth order effects. Finally, Section 8 concludes.

\section{Theoretical and Empirical Background}

\section{The Quantity/Quality Model}

Becker and Lewis (1973) showed that quality and quantity of children interact in such a way as to make it possible, with reasonable elasticity values, to observe the negative relationship between income and number of children that we observe empirically. ${ }^{1}$

Consider a quantity/quality model in which each family acts as a unitary household and has preferences over number of children $(\mathrm{N})$, quality per child $(\mathrm{Q})$, and a composite commodity (S). The optimization problem is 


$$
\max U(N, Q, S) \text { s.t. } I=P_{N} N+P_{Q} Q+P_{s} S+\Pi N Q
$$

Here $\mathrm{P}_{\mathrm{N}}, \mathrm{P}_{\mathrm{Q}}$, and $\mathrm{P}_{\mathrm{S}}$ refer to the prices of quantity, quality per child, and the composite commodity respectively. Total family income is denoted by I. The special feature of this model is that the budget constraint is nonlinear; quantity and quality enter multiplicatively, where $\Pi$ is the price-weighted sum of the cost minimizing levels of quality inputs required to increase the quality of one child by one unit. Rosenzweig and Wolpin (1980) derive the effect of an exogenous increase in family size on child quality for this model:

$$
\frac{\partial Q}{\partial N}=\frac{\left(\phi_{12}-\Pi P_{s}^{2} \lambda\right)}{\phi_{11}}
$$

where $\lambda$ is the marginal utility of income (positive), and $\phi_{\mathrm{ij}}$ is the cofactor from the ith row and jth column of the Hessian matrix from the consumer model in which there is no interaction term. Given the denominator is positive, the sign of the derivative depends principally on the value of $\phi_{12}$ (which is negative if $\mathrm{Q}$ and $\mathrm{N}$ are substitutes, positive if $\mathrm{Q}$ and $\mathrm{N}$ are complements), and the value of $\Pi$ (theorized to be positive). ${ }^{2}$ Given that $\mathrm{Q}$ and $\mathrm{N}$ are likely substitutes (suggesting $\phi_{12}$ is negative), a value of the derivative close to zero would suggest that $\Pi$ is close to zero so that the interaction term inherent in the quality/quantity model would not be supported by the data.

\section{The Empirical Literature}

\footnotetext{
${ }^{1}$ These ideas are developed further in Becker and Tomes (1976).

${ }^{2}$ Note that if $\Pi$ equals zero, the effects of an exogenous increase in family size on child quality depends only on whether $\mathrm{Q}$ and $\mathrm{N}$ are substitutes or complements.
} 
Though the theory is often cited, the empirical literature testing this model has been limited. Evidence generally supports a negative relationship between family size and child "quality" or outcomes, even after controlling for socio-economic factors. ${ }^{3}$ However, few of these findings can be interpreted as causal; family size is endogenously chosen by parents and hence may be related to other, unobservable, parental characteristics that affect child outcomes. ${ }^{4}$

This literature suffers from two additional limitations. First, typically the studies do not have large representative datasets and do not study outcomes of economic interest, such as completed education and earnings. Second, the absence of information on birth order often means that birth order effects are confounded with family size effects. While the literature is extensive, we discuss below some of the studies that attempt to deal with some or all of these problems.

Rosenzweig and Wolpin (1980), Lee (2003), and Conley (2004) all attempt to use exogenous variation in family size to determine the causal relationship between family size and child "quality". Rosenzweig and Wolpin (1980), using data from India, and Lee (2003), using data from Korea, both examine the effect of increases in fertility induced by twin births and sex of the first child, respectively, on child quality. Rosenzweig and Wolpin find that increases in fertility decrease child quality, while Lee finds that, if anything, larger families result in more educational expenditures per child. However, in both cases the sample sizes are small (25 twin pairs for Rosenzweig and Wolpin, approximately 2000 families for Lee), the estimates imprecise, and any family size effect could be confounded by the omission of birth order controls.

\footnotetext{
${ }^{3}$ See Blake (1989) and the numerous studies cited therein.
} 
In one of the most thorough studies to date, Conley (2004) uses U.S. Census data from 1980 and 1990 to examine the effect of family size on private school attendance and the probability a child is "held back". To identify the causal effect of family size, he uses the sex composition of the first two children as an exogenous source of variation in family size; parents who have two same-sex children are more likely to have a third than the same parents who have two opposite sex children. ${ }^{5}$ Using this as his instrument, Conley finds a significant negative effect of family size on private school attendance and whether a child is held back; when he analyzes the effects separately for first-born children and later children, he finds the effects are significant only for later-born children. However, his work is limited by the absence of better data; because of the structure of the Census data, he only has access to intermediate outcomes that may be weak proxies for outcomes later in life, and does not know the structure of the family for families in which some individuals do not live in the household. Also, a recent literature suggests that sex composition may have direct effects on child outcomes (for example, Dahl and Moretti, 2004, Butcher and Case, 1994; Conley, 2000; Deschenes, 2002). Such effects imply that sex composition may not be a valid instrument for family size. ${ }^{6}$

\footnotetext{
${ }^{4}$ There is also a literature examining the effect of family size on parental outcomes. See, for example, Bronars and Grogger (1994) and Angrist and Evans (1998).

${ }^{5}$ Goux and Maurin (2004) also use this instrument with French data and find no significant effect of family size on the probability of being held back. However, this result is difficult to interpret as they also include a variable measuring overcrowding in the home.

${ }^{6}$ Another strategy applied in the literature is to use siblings and difference out family level fixed effects. Guo and VanWey (1999) use data from the NLSY to evaluate the impact of family size on test scores. Although they are able to replicate the OLS pattern of a negative relationship between family size and children's outcomes, the authors find little support for this relationship when they do the within-sibling or within-individual analysis. However, this strategy requires strong assumptions about parental decisionmaking, relies on very small samples, and is identified from very small differences in family size. Phillips (1999) provides as thoughtful critique of this work, pointing out that, though suggestive, there are a number of factors that could explain these results even if there is an effect of family size on children's outcomes.
} 


\section{Data}

Our data are from matched administrative files that cover the entire population of Norway who were aged 16-74 at some point during the 1986 to 2000 interval. We restrict our sample to children who are at least 25 years of age so almost all have completed their education. ${ }^{7}$ Educational attainment is reported by the educational establishment itself directly to Statistics Norway, thereby minimizing any measurement error due to misreporting. The data also contain identifiers that allow one to match parents to children and siblings to each other. ${ }^{8}$ Given that we observe year of birth, we are able to construct indicators for the birth order of each child. Data on twin status is also available from Statistics Norway. A twin birth occurs in approximately $1.5 \%$ of families.

Our family size measure is completed family size. We have two sources of this information in that we have data on both the total number of children born to the mother (from the Families and Demographics file from Statistics Norway) as well as a count of the number of children who are sixteen or over in the 1986-2000 interval. These numbers agree in $84 \%$ of cases. The primary reason for disagreement is families with children who are too young to be in the $1986-2000$ data (14\% of cases). We calculate family size as being equal to the maximum of the number of children reported in the Families and Demographic File, and the number of children we count in the 1986-2000 files. We restrict our sample to families in which the mother and all children are alive (and thus observed in our data) at some point between 1986 and 2000. By doing this, we exclude

\footnotetext{
${ }^{7} 4.6 \%$ of our sample are still in school.

${ }^{8}$ When matching children to parents, we match using the mother's identifier, as almost all children over this period would have grown up with their mother. However, for a small proportion of children (2\%) the father differs across children in the family, and for a larger proportion (16\%) the father of some of the children is unknown to Statistics Norway (so the father may be different across children). We have verified that all results are robust to excluding families in which the father identifier differs across children or is missing for some children.
} 
families with children younger than 16 in 2000 . This makes it fairly certain that we have completed family size, as it is unlikely that a child of 25 who has no siblings aged less than 16 will subsequently have another sibling. Also, it allows us to accurately calculate birth order and the spacing measures used in the paper. Table 1 presents summary statistics for our sample and Table 2 shows the distribution of family sizes in our sample. About $18 \%$ of families have one child, $41 \%$ have $2,27 \%$ have $3,10 \%$ have 4 , and about $5 \%$ have 5 or more.

\section{Methodology and Results}

We take two approaches to distinguishing the true causal effect of family size on children's education. The first approach is to include controls for family background characteristics and birth order in order to examine how much of the estimated effect of family size on child education can be instead attributed to these observable factors. Our second approach implements two stage least squares (2SLS) using the birth of twins as a source of exogenous variation in family size.

In Tables 3 and 3a, we show the mean educational attainment and the distribution of education in the family by family size. There are two very clear findings. First, only children have much lower education than the average child in 2 or 3 child families. Indeed, only children have approximately the same level of education as children from 4 child families. Second, from family sizes of 2 to $10+$, we see a monotonic relationship that greater family size accompanies lower average educational attainment. This observed negative relationship is generally found throughout the literature. ${ }^{9}$

\footnotetext{
${ }^{9}$ The negative effect of being an only child is sometimes found in the literature. See, for example, Hauser and Kuo (1998).
} 


\section{Regression Results}

The unconditional relationship between family size and education is only suggestive; for example, it could simply represent cohort effects, as we know that family sizes have declined over time as educational attainment has increased. To better understand the relationship, we regress education of children on family size, cohort indicators (one for each year of birth), mother's cohort indicators (one for each year of birth), and a female indicator.

The estimates are reported in Columns 1-3 of Table 4a. In the first column, we report estimates for a linear specification of family size. The highly significant coefficient of -0.18 implies that, on average, adding one child to completed family size reduces average educational attainment of the children by just less than one fifth of a year. ${ }^{10}$ Because Table 3 suggests monotonicity of the effects of family size with the exception of only child families, in the third column of Table $4 \mathrm{a}$ we augment the linear specification with a dummy variable indicating whether the individual is an only child. The estimates suggest that only children receive $0.3(0.53-0.23)$ years less schooling than the average education of children in 2-child families. Also, each subsequent increment in family size reduces average attainment by almost one quarter of a year of education. Finally, in Column 2, we replace the linear specification with indicator variables for family size. ${ }^{11}$ We observe the same pattern -- a penalty for only children, and a monotonically decreasing average educational attainment for families of sizes 2 to 10 or more.

\footnotetext{
${ }^{10}$ In this regression, as in all others in the paper, the reported standard errors allow for arbitrary correlation between errors for any two children in the same family.

${ }^{11}$ Because very few families have more than 10 children, we have placed all families with 10 or more children in the same category.
} 


\section{Controlling for Family Background Characteristics}

We next examine whether our results are somehow an artifact of omitted family background controls. In Columns 4-6 of Table 4a, we report analogous estimates in which we add indicator variables for father's and mother's education level (one for each year of education), and father's cohort (one for each birth year). ${ }^{12}$ Adding these controls cuts the family size effects approximately in half -- the effect of the linear term is now 0.095. Likewise, the negative effect of being an only child is reduced in this specification. However, even these smaller effects are still quite large as is clear from the coefficients on the dummy variables -- children in families of 10 or more have on average 0.7 of a year less schooling than children in two child families.

\section{Controlling for Birth Order}

In the estimates so far, we may be confounding the effects of family size with those of birth order. We next add nine dummy variables representing second child, third child, etc. with the final dummy variable equaling one if the child is the tenth child or greater. The excluded category is first child. These results are reported in Table $4 \mathrm{~b}$. Although still statistically significant, the family size effects are reduced to close to zero - the coefficient on the linear term is now -0.01 - with the addition of the birth order dummies. This becomes -0.04 when the only child dummy is added to the specification. Although statistically significant, these numbers are much smaller than before and suggest that family size has very little impact on educational attainment. This impression 
is strengthened by the small coefficients on the family size dummy variables, many of which are now statistically insignificant. Note that this is particularly interesting given that our priors suggest that family size coefficients are likely biased upwards (in absolute terms) due to the negative relationship between unincluded family characteristics (such as income) and family size. ${ }^{13}$

We estimate the regression by birth order in Table 5. Interestingly, we find relatively small effects of family size at each birth order. The differences across birth order are small and most coefficients are statistically insignificant. It does not appear that any one birth order is particularly adversely affected by larger family size, suggesting again that family size effects are very weak once birth order is controlled for.

\section{Using Twins as an Instrument}

Rosenzweig and Wolpin (1980) first discuss the idea of using twin births as unplanned and therefore exogenous variation in family size. In their model, parents have an optimal $\mathrm{N}^{*}$ number of children. The birth of twins can vary the actual $\mathrm{N}$ from the desired $\mathrm{N}^{*}$ and it is this arguably exogenous variation that is used to estimate the effects of family size on child outcomes. Our general estimation strategy is as follows:

$$
\begin{aligned}
& E D=\beta_{0}+\beta_{1} F A M S I Z E+X \beta_{2}+\varepsilon \\
& F A M S I Z E=\alpha_{0}+\alpha_{1} T W I N+X \alpha_{2}+v
\end{aligned}
$$

In this case, ED is the education of the child and FAMSIZE is the total number of children in the family. $\mathrm{X}$ is a vector of other individual characteristics that may affect

\footnotetext{
${ }^{12}$ Information on fathers is missing for about $16 \%$ of the sample. Rather than drop these observations, we include a separate category of missing for father's cohort and father's education. As mentioned earlier, the results are robust to dropping cases with missing father information.
} 
children's educational attainment, including cohort effects for the child, cohort indicators

for both parents, the education of both parents, and birth order effects. Equation (4)

represents the first stage of the two stage least squares estimation, where equation (3) is

the second stage.

The TWIN indicator is equal to 1 if the nth birth is a multiple birth, and equal to 0

if the nth birth is a singleton. We restrict the sample to families with at least $\mathrm{n}$ births and study the outcomes of children born before the nth birth. ${ }^{14}$ In practice, we estimate the specification for values of $n$ between 2 and 6 . By restricting the sample to families with at least $\mathrm{n}$ births, we make sure that, on average, preferences over family size are the same in the families with twins at the nth birth and those with singleton births. Also, by restricting the sample to children born before birth $\mathrm{n}$, we avoid selection problems that arise because families who choose to have another child after a twin birth may differ from families who choose to have another child after a singleton birth. ${ }^{15}$

Our methodology avoids two possible pitfalls that can arise when twins are used as instruments. The first is that, even if the per-pregnancy probability of a twin birth is constant, families that desire more children are more likely to have a multiple birth (simply because they have more births). By focusing on whether a twin birth occurs for

\footnotetext{
${ }^{13}$ Unfortunately, we do not have good measures of family income for the period over which the children are growing up.

${ }^{14}$ Due to their small sample size, Rosenzweig and Wolpin (1980) use the ratio of the number of twin births to the total number of births of the mother as their instrument for completed family size. This approach is problematic, as the denominator is, at least partly, a choice variable for the mother. Thus, their instrument is still likely to be correlated with preferences of the parents over number of children. In our methodology, we are able to avoid this problem.

${ }^{15}$ In more concrete terms, if $\mathrm{n}$ equals 2 , we study the outcomes of the first child born in the family. Conceptually, we are comparing the outcomes of the first child in two-child families to that in three-child families where the extra child arises from the presence of a twin birth during the second birth. Given that most families in this period had at least two children, the sample restrictions required by this approach are not particularly severe. We similarly estimate the effect of family size on second-born children by comparing families with two singleton births, one of which has a twin birth as an outcome of the third pregnancy and the other which has a single birth in the third pregnancy.
} 
the nth birth, we avoid the problem that twin births are more likely in families that have more births.

The second possible problem is that a twin birth both increases family size and shifts downwards the birth order of children born after the twins. For example, if a twin birth occurs at the second birth, the next child born is now the fourth born-child rather than the third. Thus, any estimates using children born subsequent to a twin birth will confound family size effects with birth order effects. By only using children born before a possible twin birth, we are able to avoid this problem. ${ }^{16}$

In the Appendix, we provide further evidence that twins provide a valid source of exogenous variation, showing that twin probabilities are unrelated to parents' education and, conditional on mother's age, unrelated to the gap between births. We also examine the excludability of twin births from our regression. ${ }^{17}$

\section{Results Using Twins}

The 2SLS estimates are presented in Table 6, along with the first stage coefficients and the OLS estimates using the same sample. Again, these IV estimates present the effect of a twin birth at birth n, on the outcomes of children born prior to this birth, conditional on having at least $\mathrm{n}$ births in the family. The first stage is very strong and suggests that a twin birth increases completed family size by about 0.7 to 0.8 . As expected, twins at higher parity have a larger effect on family size, presumably because

\footnotetext{
${ }^{16}$ Rosenzweig and Wolpin (1980) use outcomes of all children and so their estimates suffer from this problem. In a later paper, Rosenzweig and Wolpin (2000), they recommend using whether or not the first born child is a twin as an instrument in this type of context. This approach would also suffer from the confluence of family size and birth order effects.

${ }^{17}$ One might also be concerned that twin probabilities differ geographically in a manner that is correlated with child education. We have found that adding county dummies or municipality dummies has no effect on the 2SLS estimates.
} 
they are more likely to push families above $\mathrm{N}^{*}$ (the optimal number of children). The $\mathrm{t}$ statistics from the first stage are typically around 60 , indicating that there are no concerns about weak instruments in this application.

The 2SLS estimate of the effect on the first child of changes in family size induced by the second birth being a twin birth is $0.038(0.047)$. This suggests no adverse effects of increased family size on educational outcomes. The equivalent estimate for families that have at least 3 births is -0.017 (0.044), and for families that have at least 4 births is $-0.018(0.060)$. Taken together, these three estimates are all less negative than the OLS estimates and are precisely enough estimated to rule out large negative effects of family size on education. These three estimates encompass the bulk of the data because, as shown in Table 1, only about $5 \%$ of families have 5 or more children. Unsurprisingly, the remaining estimates, based on families that have at least 5 births, are imprecisely estimated and not very informative. These results suggest that family size has a negligible effect on children's outcomes, once one controls for birth order.

\section{Using Same-Sex as an Instrument for Family Size}

Recent evidence suggests sex composition may have an independent impact on children's outcomes by affecting divorce probabilities, labor supply, wages, and educational outcomes. However, for completeness, we describe results using this instrument here. We study the outcomes of the first two children and use whether or not these two children are the same sex as the instrument. The first stage is strong - a coefficient of 0.089 with a standard error of 0.002 . The second stage estimate is 0.256 (0.056), implying that increased family size leads to significantly higher educational 
outcomes for children. We do not find the magnitude of this estimate credible and suspect that there are independent positive effects on outcomes of having a sibling of the same sex. Future research of our own will examine the direct effects of family sex composition on children's outcomes.

\section{Birth Order}

We have seen that birth order effects are important in that the family size effect becomes very close to zero when birth order effects are included. In addition, the estimated birth order effects themselves are quite large; they are an order of magnitude greater than the family size effects. In this section, we take a closer look at the nature of these birth order effects.

\section{Previous Literature}

Blake (1989) describes some of the factors that make empirical estimation of birth order effects difficult. First, it is necessary to fully control for family size or one will confound family size and birth order effects. Second, the presence of cohort effects in educational attainment will tend to bias results to the extent that later born children are in different cohorts from earlier born children. Thus, one needs to have multiple cohorts for each birth order and include unrestricted cohort effects. Third, it is important to include cohort effects for the parents, as, conditional on child cohort, the parents of first-borns are likely to be younger than parents of third or fourth born children. Fourth, spacing of births may differ by birth order -- for example, the last child might typically appear after 
a longer lag than the second child. If spacing has an independent effect on child outcomes, ignoring it will bias estimated birth order effects.

Studies of the effects of birth order on education have been limited by the absence of the large representative datasets necessary to thoroughly address these four issues. For example, Behrman and Taubman (1986) use data on only about 1000 individuals from the National Academy of Science/National Research Council twin sample and their adult offspring. Hanushek (1992) uses a small sample of low-income black families collected from the Gary Income Maintenance Experiment. Hauser and Sewell (1985) use the Wisconsin Longitudinal Study; their data are less than ideal as, by definition, the survey respondent has completed high school. ${ }^{18}$ Hauser and Sewell find no evidence for birth order effects; Behrman and Taubman find some evidence later children have lower education, and Hanushek observes a U-shaped pattern of achievement by birth order for large families, with oldest and youngest children doing better than middle children (although it is not clear that there are any statistically significant differences). However, all these studies estimate birth order effects quite imprecisely and, due to small samples, do not include the full set of family size indicators, cohort indicators, parental cohort indicators, and spacing controls that we use in this paper.

More recently, Iacovou (2001) uses the British National Child Development Study (NCDS) and finds that later-born children have poorer educational outcomes than earlier born. While this a very thorough study, it does suffer from some weaknesses. First the sample size is small (about 18,000 initially) and there is much attrition over time (about 50\%) so estimates are imprecise and may be subject to attrition bias. Second, all 
children in the sample are born the same week so birth order is strongly correlated with parental age at birth and it is difficult to tease out separate effects of these two variables.

The empirical literature on the effect of birth order on children's outcomes is quite extensive; despite this, however, there have been no strong conclusions due to data and methodological limitations. Because of our large dataset on the population of Norway over an extended period of time, we are able to overcome most of the limitations of the prior literature. Unlike the previous literature, we use family fixed effects models in addition to OLS.

\section{Birth Order Results}

In Table 7, we report the average education level and distribution of education by birth order. There is a clear pattern of declining education for higher birth orders. However, as with the case of family size effects, these summary statistics can be misleading in that we are not controlling for family size, cohort effects, or any other demographic characteristics that may be influencing these statistics. As a result, we estimate the relationship between birth order and educational attainment in a regression framework, using the same set of control variables as in the family size analysis.

Because of our large dataset, we can estimate regressions for the full sample as well as by family size. In Column 1 of Table 8 , we present estimates for the full sample, including a full set of family size dummies (presented in Table 4, Column 8). Relative to the first child, we observe a steady decline in child's education by birth order. Each subsequent column in Table 8 represents a separate regression for a particular family size.

\footnotetext{
${ }^{18}$ In related research, Kessler (1991) uses data from the NLSY to examine the effects of birth order and family size on wages and employment status. This paper also suffers from small sample sizes (often there
} 
If we look across row one, we can see the effect of being a "second child" (omitted category is first child) is large and negative for all family sizes. This is particularly striking, given that earlier work found somewhat different effects for different family sizes (Hanushek 1992). ${ }^{19}$ Note that the results become less precisely estimated as family sizes become larger; this is undoubtedly due to the associated decline in sample sizes. As in Column 1, we find a monotonic decline in average education as birth order increases. This result appears to be quite robust across family sizes.

As a final check, we study the effects of birth order by family size using family fixed effects. While the regressions in Table 8 included demographic controls, family fixed effects allow us to compare effects of birth order within families, thereby differencing out any family specific characteristics that are affecting all children. In addition, by estimating these equations by family size, we are also allowing for differential effects of birth order by family size. Table 9 presents these results. The estimates are almost identical to those without family fixed effects, suggesting that the estimated birth order effects do not reflect omitted family characteristics. ${ }^{20}$

\footnotetext{
are fewer than 1000 observations in the wage equations).

${ }^{19}$ In his work, Hanushek also focuses on the effect of school quality by including such measures in the estimation; although we do not have school quality measures, we have tried adding municipality effects (schools are organized at the municipality level) and municipality-year effects to control for geographical and temporal differences in school quality; the inclusion of these variables does not affect our family size or birth order conclusions.

${ }^{20}$ The estimated birth order effects could be biased if spacing has an independent effect on outcomes because spacing differs on average by birth order (see Table A1). To address this issue, we created 3 variables: (1) The number of children born within one year of the person, (2) the number of children born 2 or 3 years apart from the person, and (3) the number of children born 4 or 5 years apart from the person. Adding these variables to the fixed effects model has no appreciable effect on the estimated birth order effects (see Table A2). This specification should be treated with some caution as spacing may be optimally chosen by families and, hence, is an endogenous variable.
} 


\section{Heterogeneous Effects of Family Size and Birth Order}

To better understand what is driving our results, we stratify the data by sex and at different points of the education distribution. The first split, presented in Columns 1 and 2 of Table 10, breaks the data by sex. As one can see, the results are quite similar for men and women, with significant OLS family size effects (presented in the first row; these estimates include controls for family background) that become close to zero when birth order is controlled for (row 2). When we estimate the family size coefficients using the twin instrument, we get small and imprecisely estimated coefficients for both men and women. (The third row presents the coefficient on family size for the first child for the sample of families with at least two children, using twins at second birth as an instrument; the fourth row is the effect of family size on the first two children conditional on having at least three children using twins at third birth as an instrument, and the fifth row is the effect of family size on the first three children conditional on having at least four children using twins at fourth birth as an instrument.) While, overall, the effects of family size for women seem smaller than those for men, in both cases we see small family size effects. In contrast, birth order effects are larger for women than for men.

We next examine different points of the distribution of educational attainment to see if there is one educational group that appears to be driving our results. Table 10, Columns 3-5 present results from linear probability regressions that examine the effects of family size and birth order on the probability that an individual has 12 or more years of education (Column 3), the probability that an individual has 13 or more years of education (Column 4), and the probability that an individual has 16 or more years of 
education (Column 5). The results are quite similar in all cases, with small family size effects once birth order is controlled for and large birth order effects (although a bit smaller for the probability of having 16 or more years of education), suggesting that our results are not being driven by one particular part of the distribution.

\section{Possible Explanations for Birth Order Effects}

We next turn our attention to possible explanations for the strong birth order effects we observe. Genetic and biological differences may explain much of the outcome differences between siblings, but it is unlikely that they can explain the birth order effects we estimate. While maternal age is related to birth weight and the likelihood of birth defects, our inclusion of cohort controls for mothers and children rule out this channel. ${ }^{21}$ Typically research has found that the incidence of low birthweight decreases with parity, so we would expect later borns to be better endowed in this dimension than earlier born children (see, for example, Phung et al., 2003). In general, there are no genes for being a firstborn or a laterborn so it is unlikely that the birth order effects we find have genetic or biological causes. Below, we consider other possible explanations for the observed birth order effects.

Family Size when Young versus Completed Family Size

One rationalization of our weak family size effects and strong birth order effects is that family size matters most when children are very young and the birth order effects are capturing this. For example, suppose it is the case that what matters is family size 
when the individual is born. Family size at birth is exactly equal to birth order so this "family size" effect would be picked up by the birth order dummies. The perfect collinearity implies that this contention is untestable but we conjecture that if family size when young matters, we should see this if we create variables for family size at age 2 and family size at age 5 . Because these are not collinear with birth order, we can estimate their effects separately from birth order (and completed family size). The correlations between the four variables are in the table below:

\begin{tabular}{lllll}
\hline Correlation & Birth Order & Family Size & Family Size at 2 & Family Size at 5 \\
\hline Birth Order & 1.000 & & & \\
Family Size & 0.585 & 1.000 & & \\
Family Size at 2 & 0.919 & 0.690 & 1.000 & \\
Family Size at 5 & 0.798 & 0.833 & 0.879 & 1.000 \\
\hline
\end{tabular}

When number of children at age 2 is included in the standard specification, along with completed family size and birth order effects, the coefficient is $-0.024(0.005)$ and the coefficient on completed family size falls to $-0.008(0.003)$. The birth order effects remain large and are approximately the same size as before. When number of children at age 5 replaces number of children at age 2, it has a perverse positive coefficient of 0.066 (0.004) and the coefficient on completed family size becomes $-0.045(0.003)$. This suggests that number of children at age 5 may be too collinear with completed family size for us to get sensible results. Again, however, the birth order effects are not affected. In the fixed effects specification, the coefficient on children at age 2 is $-0.005(0.006)$ and that on children at age 5 is $0.071(0.005)$. The completed family size variable is not

\footnotetext{
${ }^{21}$ Recent research (Royer, 2003) finds that both younger and older mothers give birth to children that are less healthy in many dimensions. For example, women over 35 or under 18 are more likely to have a preterm birth than mothers aged between 26 and 29.
} 
identified, and the birth order effects remain similar in size to those in Table 10. These results are presented in Table A3.

Overall, because of collinearity problems, we do not learn much from this exercise about whether family size early in life is particularly important. However, the robustness of the birth order estimates suggests that they are not merely capturing family size effects.

\section{Optimal Stopping Model}

Another possible explanation for the birth order effects we observe is an optimal stopping model. According to this theory, if a particularly "good quality" child is born first, this may induce parents to have more children who, on average, will not be of as high a quality. Conversely, if early children are "poor quality," parents may opt to discontinue childbearing. ${ }^{22}$ This type of behavior may give rise to birth order effects because it may lead to earlier children having better endowments. However, the estimates in Tables 8 and 9 clearly cannot be fully explained by this model. For example, an optimal stopping rule cannot explain the large magnitudes of the second child effect in families with more than two children. However, we do see a "last child" effect in Tables 8 and 9. For example, the penalty to being a second child is significantly bigger in a 2child family than in a 3-child family. This also holds for larger family sizes: In the fixed effects estimates, the third child does relatively worse in 3-child families than in 4-child ones (the difference is -0.076 with a standard error of 0.025 ; analogously the difference for fourth children is $-0.110(0.046))$. For larger families, the differences become

\footnotetext{
${ }^{22}$ There is some evidence that early behaviors are reasonable predictors for later outcomes. (See Currie and Stabile, 2004).
} 
statistically insignificant. This "last child" effect is consistent with optimal stopping behavior; however, it is also consistent with Zajonc's (1976) hypothesis that last children suffer from having nobody to teach.

\section{Financial Resources}

The financial resources available for investment in children may also differ with birth order if credit markets are imperfect. Given that age-earnings profiles are upward sloping, younger parents may have fewer resources to invest in their children. However, these resources will be shared among fewer individuals. Unfortunately, we do not have information on family income during the childhood of the children under study, so we are limited in how we can examine this issue. However, we do have information on parental education which is correlated with parental income. We have segregated the sample by mother's education (Table 11, Columns 1 and 2) and find that the magnitude of the birth order effects do not differ much across education groups; if anything, birth order effects are stronger among individuals with more educated mothers, which runs counter to the expected results if financial constraints are driving the results.

\section{Urban/Rural}

Larger families may matter more or less depending on the rural/urban nature of the family environment. A large family may be beneficial on a farm but much more costly in an urban environment. If this were the case, we would see differential effects when we stratify the sample based on the population density of the municipality of the mother in 1960 (the urban group includes the 59 largest urban areas in 1960). When we 
do this in Table 11, Columns 3 and 4, the results are quite similar across the different municipality types, suggesting this cannot explain our results.

\section{Time Constraints}

Parent time constraints may also lead to birth order effects. ${ }^{23}$ If time or financial constraints are in fact affecting children's outcomes, it is likely that families in which children are spaced more widely suffer less from resource constraints (financial or time) than other families of the same size. ${ }^{24}$ Thus, for example, we have estimated the effect of being a second child in two child families and segregated the sample by the space between the two children (2 years or less, 3-5 years, $6+$ years). We find that the second child effect is actually smaller in the closely spaced families -- the coefficient is -0.19 (0.04) for the 0 - 2 group, $-0.49(0.04)$ for the $3-5$ group, and $-0.55(0.05)$ for the $6+$ group. This is not in keeping with our priors about the effects of time and resource constraints. However, child spacing is clearly not exogenous and so any conclusions derived from this exercise are only speculative in nature.

Another way to try to test the effect of parental financial or time constraints is to compare the effects of family size and birth order for earlier cohorts relative to later cohorts. Later cohorts had the benefit of more effective birth control and abortion access and, as a result, family size may have been more of a choice variable. When we stratify

\footnotetext{
${ }^{23}$ Earlier-born children may benefit from receiving more resources in the form of parental time than other children because they have fewer siblings with whom to compete. Of course, later born children may analogously benefit from getting more parental attention after the earlier-born children have moved out of the family home. In addition, there may be differences in the quality of this time, as first children will have younger, more energetic parents (who also will be more inexperienced) while later children will have older parents who have more experience with childrearing.

${ }^{24}$ Powell and Steelman (1993) focus on the effects of sibling spacing on high school completion and postsecondary school attendance using the High School and Beyond dataset. They find evidence that closely spaced siblings are disadvantageous within sibship size category.
} 
our sample based on mother's cohort (those born before 1935 versus those born after), we find similar effects for both samples. (See Table 11 Columns 5 and 6.) While birth order effects are slightly smaller in the younger sample relative to the older sample, they are still quite large and significant.

In summary, while we are confident that endowment effects are not responsible for all the birth order effects, our findings are consistent with optimal stopping being a small part of the explanation. Our tests for resource constraints suggest that these are not driving our results; however, the tests themselves are quite weak. While there are a number of other theories as to why one would see birth order effects hypothesized in the literature, these theories are not testable with our data. ${ }^{25}$

\section{Conclusions}

Traditional models of fertility involve a tradeoff between child quantity and child quality in order to justify the observed negative relationship between family income and total family size. Inherent in this model is the idea that increasing family size will have a negative effect on children's outcomes. In this paper, we attempt to test this model by examining the effect of family size using both exogenous variation in family size induced by twin births as well as extensive controls for not only parent and child cohort effects and parental education, but also birth order effects. We find evidence that there is little if

\footnotetext{
${ }^{25}$ One such theory involves parental preferences. Parental preferences may vary by birth order. If parents are focused on their old age, it may be optimal to invest more in the early-born children who are more likely to be in a position to offer support by the time the parents hope to retire. On the other hand, if parents are focused on their career when they are younger, they may be less willing to spend time with their children than when they are older and more established professionally. Finally, there may be diminishing marginal utility from children. In this case, parents get less utility from spending time with later children than they did with earlier ones.
} 
any family size effect once birth order is controlled for; this is true when we estimate the relationship with controls for birth order, instrument family size with twin births, or estimate the relationship between child education and family size separately for each birth order.

In contrast, we find very large and robust effects of birth order on child education. To get a sense of the magnitude of these effects, the difference in educational attainment between the first child and the fifth child in a five child family is roughly equal to the difference between black and white educational attainment calculated from the 2000 census. Given that family sizes continue to decline in developing countries, these results suggest that the children may not necessarily be better off than if their family had been larger. Our results imply that, though average child outcomes may improve, there may be little effect on first-born children.

In addition, these sizeable birth order effects have potential methodological implications: Researchers using sibling fixed effects models to study economic outcomes may obtain biased estimates unless they take account of birth order effects in estimation.

Our findings so far are quite provocative; if, in fact, there is no independent tradeoff between family size and child quality, perhaps we need to revisit models of fertility and reconsider what should be included in the "production function" of children. What other explanations will generate the patterns we observe in the data? Clearly, our results suggest a need for more work in this area. 


\section{References}

Angrist, Joshua D. and William N. Evans, "Children and Their Parents' Labor Supply: Evidence from Exogenous Variation in Family Size." American Economic Review, Vol. 88, No. 3, June, 1998, 450-477.

Becker, Gary S., "An Economic Analysis of Fertility” In Becker, ed., Demographic and Economic Change in Developed Countries. Princeton, N.J.: Princeton University Press 1960.

Becker, Gary S. and H. Gregg Lewis "On the Interaction Between the Quantity and Quality of Children” Journal of Political Economy, 1973, Vol. 81, No. 2, S279S288.

Becker, Gary S. and Nigel Tomes, "Child Endowments and the Quantity and Quality of Children” Journal of Political Economy, 1976, Vol. 84, No. 4, S143-S162.

Behrman, Jere R. and Paul Taubman, "Birth Order, Schooling, and Earnings." Journal of Labor Economics, 1986. Vol 4, No. 3.

Blake, Judith, Family Size and Achievement, 1989, University of California Press, Berkeley and Los Angeles.

Bronars, Stephen G. and Jeff Grogger, "The Economic Consequences of Unwed Motherhood: Using Twin Births as a Natural Experiment." American Economic Review, Vol 84, No. 5. December, 1994. 1141-1156.

Butcher, Kristin F., and Anne Case (1994), "The Effect of Sibling Sex Composition on Women's Education and Earnings", Quarterly Journal of Economics, Vol. CIX, Issue 3, 531-563.

Conley, Dalton, "What is the "true" effect of sibship size and birth order on education? Instrumental variable estimates from exogenous variation in fertility." Mimeo, 2004.

Conley, Dalton, "Sibling Sex Composition: Effects on Educational Attainment" (2000), Social Science Research, Vol. 29, 441-457.

Currie, Janet and Mark Stabile, "Child Mental Health and Human Capital Accumulation: The Case of ADHD.” Working paper, July 2004.

Dahl, Gordon and Enrico Moretti, "The Demand for Sons: Evidence from Divorce, Fertility, and Shotgun Marriage.” Working paper, 2004. 
Deschenes, Olivier, "Estimating the Effects of Family Background on the Return to Schooling" (March 1, 2002). Department of Economics, UCSB. Departmental Working Papers. Paper 10-02.

Goux, Dominique, and Eric Maurin, “The Effect of Overcrowded Housing on Children's Performance at School.”, Mimeo, June 2004.

Guo, Guang and Leah K. VanWey, "Sibship Size and Intellectual Development: Is the Relationship Causal?" American Sociological Review, 1999, Vol 64, April.

Hanushek, Eric A., "The Trade-off between Child Quantity and Quality" Journal of Political Economy, 1992. Vol 100, No. 1.

Hauser, Robert M., and Hsiang-Hui Daphne Kuo (1998), "Does the Gender Composition of Sibships affect Women's Educational Attainment?", Journal of Human Resources, Vol. 33, No. 3, 644-657.

Hauser, Robert M., and William H. Sewell (1985), "Birth Order and Educational Attainment in Full Siblings", American Educational Research Journal, Vol. 22, No. 1, 1-23.

Iacovou, Maria (2001), "Family Composition and Children's Educational Outcomes", Working Paper.

Jacobsen, Joyce P., James Wishart Pearce III, and Joshua L. Rosenbloom, "The Effects of Childbearing on Married Women's Labor Supply and Earnings: Using Twin Births as a Natural Experiment." Journal of Human Resources, Summer 1999.

Kessler, Daniel, "Birth Order, Family Size, and Achievement: Family Structure and Wage Determination." Journal of Labor Economics, 1991, Vol 9, No. 4. October.

Lee, Jungmin, "Children and Household Education Decisions: An Asian Instrument." Working Paper, 2003.

Phillips, Meredith, "Sibship Size and Academic Achievement: What We Now Know and What We Still Need to Know-Comment on Guo \& VanWey." American Sociological Review, 1999, Vol 64.

Phung H, Bauman A, Nguyen TV, Young L, Tran M, Hillman K, (2003) "Risk factors for low birth weight in a socio-economically disadvantaged population: Parity, marital status, ethnicity and cigarette smoking”, European Journal of Epidemiology 18 (3): 235-243.

Powell, Brian and Lala Carr Steelman, "The Educational Benefits of Being Spaced Out: Sibship Density and Educational Progress." American Sociological Review, 1993, Vol 58, June. 
Rosenzweig Mark R., and Kenneth I. Wolpin, "Testing the Quantity-Quality Fertility Model: The Use of Twins as a Natural Experiment", Econometrica, Vol. 48, No. 1, 227-240 (Jan, 1980).

Rosenzweig Mark R., and Kenneth I. Wolpin, "Natural "Natural Experiments" in Economics", Journal of Economic Literature (2000).

Royer, Heather, "What All Women (and Some Men) Want to Know: Does Maternal Age Affect Infant Health?" Working Paper 2003.

Zajonc R. B., "Family Configuration and Intelligence" Science, Vol. 192, 227-236, 1976. 
Table 1

Summary Statistics-Full Sample

\begin{tabular}{lcc}
\hline & Mean & Standard Deviation \\
\hline Age in 2000 & 38 & 8.5 \\
Female & .48 & .50 \\
Education & 12.2 & 2.4 \\
Mother's Education & 9.5 & 2.4 \\
Father's Education & 10.4 & 3.0 \\
Mother's Age in 2000 & 65 & 10.5 \\
Father's Age in 2000 & 67 & 10.0 \\
Number of Children & 2.96 & 1.3 \\
Twins in Family & .015 & .12 \\
\hline N=1,427,107 & & \\
\hline
\end{tabular}

Table 2

Number of Children in the Family (by Family)

\begin{tabular}{lrc}
\hline & Frequency & Percentage \\
\hline 1 & 116,000 & 18 \\
2 & 264,626 & 41 \\
3 & 171,941 & 26.6 \\
4 & 63,809 & 9.9 \\
5 & 20312 & 3.1 \\
6 & 6674 & 1.0 \\
7 & 2251 & .4 \\
8 & 822 & .1 \\
9 & 350 & .05 \\
$10+$ & 250 & .04 \\
\hline
\end{tabular}


Table 3

Average Education by Number of Children in Family

\begin{tabular}{lccc}
\hline & Education & $\begin{array}{c}\text { Mother's } \\
\text { Education }\end{array}$ & $\begin{array}{c}\text { Father's } \\
\text { Education }\end{array}$ \\
\hline 1 & 12.0 & 9.2 & 10.1 \\
2 & 12.4 & 10.0 & 10.8 \\
3 & 12.3 & 9.9 & 10.7 \\
4 & 12 & 9.4 & 10.2 \\
5 & 11.7 & 8.9 & 9.6 \\
6 & 11.4 & 8.5 & 9.2 \\
7 & 11.2 & 8.4 & 8.9 \\
8 & 11.2 & 8.2 & 8.8 \\
9 & 11.0 & 8.1 & 8.7 \\
$10+$ & 11.0 & 8.0 & 8.8 \\
\hline
\end{tabular}

Table 3a

Educational Distribution by Number of Children in Family (Fraction in each Category, by Family Size)

\begin{tabular}{lccccc}
\hline & $<10$ Years & $10-11$ Years & 12 Years & $13-15$ Years & $16+$ Years \\
\hline 1 & .12 & .31 & .25 & .18 & .13 \\
2 & .08 & .26 & .31 & .21 & .14 \\
3 & .09 & .28 & .30 & .19 & .14 \\
4 & .11 & .32 & .29 & .17 & .12 \\
5 & .15 & .35 & .27 & .14 & .10 \\
6 & .18 & .37 & .25 & .12 & .08 \\
7 & .21 & .37 & .24 & .11 & .08 \\
8 & .21 & .37 & .24 & .11 & .07 \\
9 & .22 & .37 & .25 & .10 & .06 \\
$10+$ & .22 & .37 & .26 & .10 & .05 \\
\hline
\end{tabular}


Table 4a

Effect of Family Size on Children's Education

\begin{tabular}{|c|c|c|c|c|c|c|}
\hline $\begin{array}{l}\text { Dependent Variable: } \\
\text { Child's Education }\end{array}$ & No Der & nographic C & ontrols & With D & mographic & Controls \\
\hline Number of Children & $\begin{array}{c}-.18^{*} \\
(002)\end{array}$ & & $\begin{array}{l}-.23^{*} \\
(003)\end{array}$ & $\begin{array}{l}-.09^{*} \\
(.002)\end{array}$ & & $\begin{array}{l}-.11^{*} \\
(.002)\end{array}$ \\
\hline Only Child & & & $\begin{array}{r}-.53^{*} \\
(.01)\end{array}$ & & & $\begin{array}{l}-.21^{*} \\
(.009)\end{array}$ \\
\hline 2 Child Family & & $\begin{array}{l}.27^{*} \\
(.01)\end{array}$ & & & $\begin{array}{l}.096^{*} \\
(.008)\end{array}$ & \\
\hline 3 Child Family & & $\begin{array}{l}.13 * \\
(.01)\end{array}$ & & & $\begin{array}{l}.001^{*} \\
(.008)\end{array}$ & \\
\hline 4 Child Family & & $\begin{array}{l}-.17^{*} \\
(.01)\end{array}$ & & & $\begin{array}{l}-.15^{*} \\
(.009)\end{array}$ & \\
\hline 5 Child Family & & $\begin{array}{r}-.48^{*} \\
(.01)\end{array}$ & & & $\begin{array}{l}-.28^{*} \\
(.012)\end{array}$ & \\
\hline 6 Child Family & & $\begin{array}{l}-.73^{*} \\
(.02)\end{array}$ & & & $\begin{array}{l}-.39^{*} \\
(.018)\end{array}$ & \\
\hline 7 Child Family & & $\begin{array}{c}-.88^{*} \\
(.03)\end{array}$ & & & $\begin{array}{l}-.47^{*} \\
(.029)\end{array}$ & \\
\hline 8 Child Family & & $\begin{array}{c}-.95^{*} \\
(.05)\end{array}$ & & & $\begin{array}{l}-.50^{*} \\
(.045)\end{array}$ & \\
\hline 9 Child Family & & $\begin{array}{c}-1.04 * \\
(.07)\end{array}$ & & & $\begin{array}{l}-.52^{*} \\
(.065)\end{array}$ & \\
\hline 10 Child Family & & $\begin{array}{l}-1.2^{*} \\
(.08)\end{array}$ & & & $\begin{array}{l}-.61^{*} \\
(.075)\end{array}$ & \\
\hline $\mathrm{N}$ & $1,427,107$ & $1,427,107$ & $1,427,107$ & $1,427,107$ & $1,427,107$ & $1,427,107$ \\
\hline R-Squared & .0465 & .0498 & .0492 & .1949 & .1954 & .1953 \\
\hline
\end{tabular}

* indicates statistical significance at the $5 \%$ level. Standard errors (in parentheses) allow for correlation of errors within family. All regressions include indicators for age, mother's age, and sex. Demographic controls include indicators for mother's education, father's education, and father's age. 
Table 4b

Effect of Family Size on Children's Education

Including Demographic Controls and Birth Order

\begin{tabular}{|c|c|c|c|}
\hline Number of Children & $\begin{array}{l}-.012 * \\
(.002)\end{array}$ & & $\begin{array}{l}-.05^{*} \\
(.003)\end{array}$ \\
\hline Only Child & & & $\begin{array}{l}-.32 * \\
(.009)\end{array}$ \\
\hline 2 Child Family & & $\begin{array}{c}.26^{*} \\
(.008)\end{array}$ & \\
\hline 3 Child Family & & $\begin{array}{l}.27^{*} \\
(.009)\end{array}$ & \\
\hline 4 Child Family & & $\begin{array}{l}.19^{*} \\
(.010)\end{array}$ & \\
\hline 5 Child Family & & $\begin{array}{l}.11^{*} \\
(.013)\end{array}$ & \\
\hline 6 Child Family & & $\begin{array}{c}.03 \\
(.019)\end{array}$ & \\
\hline 7 Child Family & & $\begin{array}{c}-.02 \\
(.031)\end{array}$ & \\
\hline 8 Child Family & & $\begin{array}{c}-.04 \\
(.046)\end{array}$ & \\
\hline 9 Child Family & & $\begin{array}{c}-.04 \\
(.067)\end{array}$ & \\
\hline 10 Child Family & & $\begin{array}{c}-.09 \\
(.079)\end{array}$ & \\
\hline Second Child & $\begin{array}{l}-.29 * \\
(.004)\end{array}$ & $\begin{array}{l}-.34^{*} \\
(.004)\end{array}$ & $\begin{array}{l}-.34^{*} \\
(.004)\end{array}$ \\
\hline Third Child & $\begin{array}{l}-.49 * \\
(.007)\end{array}$ & $\begin{array}{l}-.54^{*} \\
(.007)\end{array}$ & $\begin{array}{l}-.52 * \\
(.007)\end{array}$ \\
\hline Fourth Child & $\begin{array}{l}-.63 * \\
(.010)\end{array}$ & $\begin{array}{l}-.62 * \\
(.010)\end{array}$ & $\begin{array}{l}-.63^{*} \\
(.010)\end{array}$ \\
\hline Fifth Child & $\begin{array}{l}-.72 * \\
(.015)\end{array}$ & $\begin{array}{l}-.65^{*} \\
(.015)\end{array}$ & $\begin{array}{l}-.68^{*} \\
(.015)\end{array}$ \\
\hline Sixth Child & $\begin{array}{l}-.78^{*} \\
(.023)\end{array}$ & $\begin{array}{l}-.66^{*} \\
(.023)\end{array}$ & $\begin{array}{l}-.71^{*} \\
(.023)\end{array}$ \\
\hline Seventh Child & $\begin{array}{l}-.85^{*} \\
(.037)\end{array}$ & $\begin{array}{l}-.71 * \\
(.037)\end{array}$ & $\begin{array}{l}-.75^{*} \\
(.037)\end{array}$ \\
\hline Eighth Child & $\begin{array}{c}-.75^{*} \\
(.059)\end{array}$ & $\begin{array}{l}-.61^{*} \\
(.057)\end{array}$ & $\begin{array}{l}-.62^{*} \\
(.059)\end{array}$ \\
\hline Ninth Child & $\begin{array}{l}-.94 * \\
(.081)\end{array}$ & $\begin{array}{l}-.80^{*} \\
(.082)\end{array}$ & $\begin{array}{l}-.77^{*} \\
(.081)\end{array}$ \\
\hline Tenth Child & $\begin{array}{l}-1.13^{*} \\
(.116)\end{array}$ & $\begin{array}{l}-.98^{*} \\
(.111)\end{array}$ & $\begin{array}{l}-.89^{*} \\
(.114)\end{array}$ \\
\hline $\mathrm{N}$ & $1,427,107$ & $1,427,107$ & $1,427,107$ \\
\hline R-Squared & .1989 & .1999 & .1998 \\
\hline
\end{tabular}




\section{Table 5}

\section{Effect of Family Size on Children's Education}

Estimated by Birth Order

Dependent Variable: Child Education

First Child $(\mathrm{N}=641,956)$

Number of Children in Family

$-.067 *$

Only Child

Second Child (N=458,284)

Number of Children in Family

Third Child ( $\mathrm{N}=211,346)$

Number of Children in Family

$-.042 *$

Fourth Child ( $\mathrm{N}=76,524)$

Number of Children in Family

Fifth Child ( $\mathrm{N}=25,361)$

Number of Children in Family

Sixth Child $(\mathrm{N}=8,600)$

Number of Children in Family

Seventh Child $(\mathrm{N}=3,029)$

Number of Children in Family

Eighth Child $(\mathrm{N}=1,190)$

Number of Children in Family

Ninth Child $(\mathrm{N}=476)$

Number of Children in Family

* indicates statistical significance at the 5\% level. Standard errors (in parentheses) allow for correlation of errors within family. Regressions are run separately by birth order; each coefficient represents the effect of family size on the outcomes of children of that particular birth order. All regressions include indicators for age, mother's age, and sex. Demographic controls include indicators for mother's education, father's education, and father's age. 
Table 6

Effect of Family Size on Education of Children

Using Presence of Twin Birth As an Instrument

Looking at Children Born Before Potential Twin Birth

\begin{tabular}{|c|c|c|c|c|}
\hline & $\begin{array}{l}\text { OLS (Twins } \\
\text { Sample) }\end{array}$ & First Stage & Second Stage & $\mathrm{N}$ \\
\hline $\begin{array}{l}\text { Instrument: Twin at Second Birth } \\
\text { (Sample: First child in families with } \\
2 \text { or more births) }\end{array}$ & & $\begin{array}{l}.675^{*} \\
(.013)\end{array}$ & & 525,956 \\
\hline Number of Children in Family & $\begin{array}{l}-.060 * \\
(.003)\end{array}$ & & $\begin{array}{r}.038 \\
(.047) \\
\end{array}$ & \\
\hline $\begin{array}{l}\text { Instrument: Twin at Third Birth } \\
\text { (Sample: First and second children } \\
\text { in families with } 3 \text { or more births) }\end{array}$ & & $\begin{array}{l}.752^{*} \\
(.012)\end{array}$ & & 502,525 \\
\hline Number of Children in Family & $\begin{array}{l}-.076^{*} \\
(.004)\end{array}$ & & $\begin{array}{l}-.018 \\
(.044)\end{array}$ & \\
\hline Second Child & $\begin{array}{l}-.314^{*} \\
(.006)\end{array}$ & & $\begin{array}{l}-.324 * \\
(.010)\end{array}$ & \\
\hline $\begin{array}{l}\text { Instrument: Twin at Fourth Birth } \\
\text { (Sample: First, second and third } \\
\text { children in families with } 4 \text { or more } \\
\text { births) }\end{array}$ & & $\begin{array}{l}.810^{*} \\
(.016)\end{array}$ & & 261,459 \\
\hline Number of Children in Family & $\begin{array}{l}-.059^{*} \\
(.006)\end{array}$ & & $\begin{array}{l}-.018 \\
(.060)\end{array}$ & \\
\hline Second Child & $\begin{array}{l}-.306^{*} \\
(.010)\end{array}$ & & $\begin{array}{l}-.313^{*} \\
(.013)\end{array}$ & \\
\hline Third Child & $\begin{array}{l}-.533^{*} \\
(.013)\end{array}$ & & $\begin{array}{l}-.546^{*} \\
(.023)\end{array}$ & \\
\hline $\begin{array}{l}\text { Instrument: Twin at Fifth Birth } \\
\text { (Sample: First through fourth } \\
\text { children in families with } 5 \text { or more } \\
\text { births) }\end{array}$ & & $\begin{array}{l}.699 * \\
(.026)\end{array}$ & & 111,888 \\
\hline Number of Children in Family & $\begin{array}{l}-.039 * \\
(.009)\end{array}$ & & $\begin{array}{l}-.142 \\
(.111)\end{array}$ & \\
\hline Second Child & $\begin{array}{l}-.269^{*} \\
(.017)\end{array}$ & & $\begin{array}{l}-.258^{*} \\
(.023)\end{array}$ & \\
\hline Third Child & $\begin{array}{l}-.485^{*} \\
(.021)\end{array}$ & & $\begin{array}{l}-.457^{*} \\
(.038)\end{array}$ & \\
\hline Fourth Child & $\begin{array}{l}-.640^{*} \\
(.026)\end{array}$ & & $\begin{array}{l}-.593 * \\
(.057)\end{array}$ & \\
\hline
\end{tabular}




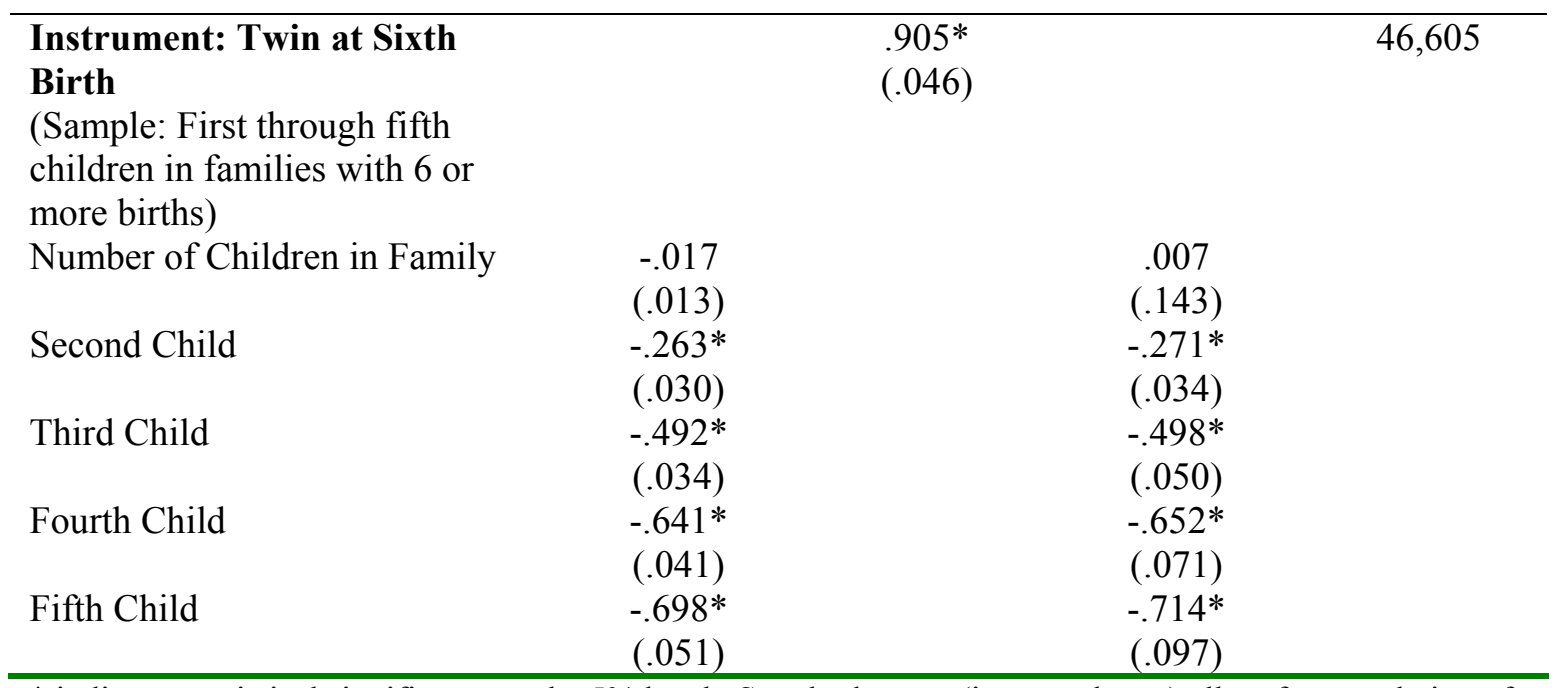

* indicates statistical significance at the 5\% level. Standard errors (in parentheses) allow for correlation of errors within family. All regressions include indicators for age, mother's age, mother's education, father's education, father's age, and sex. 
Table 7

Average Educational Attainment and Distribution of Education

by Birth Order

\begin{tabular}{lccccccr}
\hline Birth Order & $\begin{array}{c}\text { Avg. Educational } \\
\text { Attainment }\end{array}$ & $\begin{array}{c}<10 \\
\text { Years }\end{array}$ & $\begin{array}{c}10-11 \\
\text { Years }\end{array}$ & $\begin{array}{c}12 \\
\text { Years }\end{array}$ & $\begin{array}{c}13-15 \\
\text { Years }\end{array}$ & $\begin{array}{c}16+ \\
\text { Years }\end{array}$ & $\mathrm{N}$ \\
\hline 1 & 12.25 & .10 & .28 & .28 & .20 & .15 & 641,956 \\
2 & 12.16 & .10 & .29 & .30 & .19 & .12 & 458,284 \\
3 & 12.05 & .10 & .30 & .31 & .18 & .11 & 211,346 \\
4 & 11.88 & .12 & .31 & .32 & .16 & .10 & 76,524 \\
5 & 11.70 & .13 & .33 & .31 & .14 & .08 & 25,361 \\
6 & 11.58 & .14 & .35 & .31 & .13 & .07 & 8,600 \\
7 & 11.47 & .16 & .36 & .30 & .12 & .07 & 3,029 \\
8 & 11.57 & .15 & .34 & .31 & .13 & .07 & 1,190 \\
9 & 11.35 & .13 & .39 & .32 & .11 & .04 & 476 \\
$10+$ & 11.26 & .16 & .36 & .32 & .14 & .01 & 341 \\
\hline
\end{tabular}


Table 8

Effect of Birth Order on Children's Education

Estimated by Family Size

\begin{tabular}{|c|c|c|c|c|c|c|c|c|c|c|}
\hline & $\begin{array}{c}\text { All } \\
\text { Families }^{1}\end{array}$ & $\begin{array}{c}\text { Two } \\
\text { Child } \\
\text { Family } \\
\end{array}$ & $\begin{array}{c}\text { Three } \\
\text { Child } \\
\text { Family }\end{array}$ & $\begin{array}{c}\text { Four } \\
\text { Child } \\
\text { Family } \\
\end{array}$ & $\begin{array}{c}\text { Five } \\
\text { Child } \\
\text { Family }\end{array}$ & $\begin{array}{c}\text { Six } \\
\text { Child } \\
\text { Family }\end{array}$ & $\begin{array}{c}\text { Seven } \\
\text { Child } \\
\text { Family } \\
\end{array}$ & $\begin{array}{c}\text { Eight } \\
\text { Child } \\
\text { Family }\end{array}$ & $\begin{array}{c}\text { Nine } \\
\text { Child } \\
\text { Family }\end{array}$ & $\begin{array}{c}\text { Ten } \\
\text { Child } \\
\text { Family }\end{array}$ \\
\hline Second Child & $\begin{array}{l}-.34^{*} \\
(.004)\end{array}$ & $\begin{array}{l}-.378^{*} \\
(.007)\end{array}$ & $\begin{array}{l}-.318^{*} \\
(.007)\end{array}$ & $\begin{array}{l}-.328^{*} \\
(.012)\end{array}$ & $\begin{array}{c}-.279^{*} \\
(.020)\end{array}$ & $\begin{array}{c}-.254^{*} \\
(.035)\end{array}$ & $\begin{array}{l}-.255^{*} \\
(.063)\end{array}$ & $\begin{array}{l}-.441^{*} \\
(.104)\end{array}$ & $\begin{array}{c}-.284^{*} \\
(.172)\end{array}$ & $\begin{array}{l}-.350^{*} \\
(.174)\end{array}$ \\
\hline Third Child & $\begin{array}{l}-.54^{*} \\
(.007)\end{array}$ & & $\begin{array}{l}-.611^{*} \\
(.011)\end{array}$ & $\begin{array}{l}-.558 * \\
(.015)\end{array}$ & $\begin{array}{c}-.489^{*} \\
(.024)\end{array}$ & $\begin{array}{c}-.490^{*} \\
(.040)\end{array}$ & $\begin{array}{l}-.456^{*} \\
(.072)\end{array}$ & $\begin{array}{l}-.627 * \\
(.134)\end{array}$ & $\begin{array}{c}-.595^{*} \\
(.189)\end{array}$ & $\begin{array}{l}-.626^{*} \\
(.208)\end{array}$ \\
\hline Fourth Child & $\begin{array}{l}-.62 * \\
(.010)\end{array}$ & & & $\begin{array}{l}-.767 * \\
(.021)\end{array}$ & $\begin{array}{c}-.646^{*} \\
(.030)\end{array}$ & $\begin{array}{c}-.658^{*} \\
(.047)\end{array}$ & $\begin{array}{l}-.614 * \\
(.081)\end{array}$ & $\begin{array}{l}-.695^{*} \\
(.134)\end{array}$ & $\begin{array}{c}-.480 * \\
(.199)\end{array}$ & $\begin{array}{l}-.877^{*} \\
(.226)\end{array}$ \\
\hline Fifth Child & $\begin{array}{l}-.65^{*} \\
(.015)\end{array}$ & & & & $\begin{array}{c}-.816^{*} \\
(.040)\end{array}$ & $\begin{array}{c}-.701^{*} \\
(.059)\end{array}$ & $\begin{array}{l}-.702^{*} \\
(.097)\end{array}$ & $\begin{array}{l}-.829 * \\
(.149)\end{array}$ & $\begin{array}{l}-.662 * \\
(.222)\end{array}$ & $\begin{array}{l}-.936^{*} \\
(.245)\end{array}$ \\
\hline Sixth Child & $\begin{array}{l}-.66^{*} \\
(.023)\end{array}$ & & & & & $\begin{array}{c}-.870^{*} \\
(.073)\end{array}$ & $\begin{array}{l}-.747^{*} \\
(.117)\end{array}$ & $\begin{array}{c}-.806^{*} \\
(.171)\end{array}$ & $\begin{array}{c}-.638^{*} \\
(.257)\end{array}$ & $\begin{array}{c}-1.042 * \\
(.262)\end{array}$ \\
\hline Seventh Child & $\begin{array}{l}-.71 * \\
(.037)\end{array}$ & & & & & & $\begin{array}{l}-.870^{*} \\
(.141)\end{array}$ & $\begin{array}{c}-1.016 * \\
(.203)\end{array}$ & $\begin{array}{c}-.696^{*} \\
(.271)\end{array}$ & $\begin{array}{c}-1.241 * \\
(.287)\end{array}$ \\
\hline Eighth Child & $\begin{array}{l}-.61 * \\
(.057)\end{array}$ & & & & & & & $\begin{array}{c}-1.004^{*} \\
(.236)\end{array}$ & $\begin{array}{l}-.460 \\
(.319)\end{array}$ & $\begin{array}{c}-1.445^{*} \\
(.314)\end{array}$ \\
\hline Ninth Child & $\begin{array}{l}-.80^{*} \\
(.082)\end{array}$ & & & & & & & & $\begin{array}{c}-.816^{*} \\
(.373)\end{array}$ & $\begin{array}{c}-1.569 * \\
(.343)\end{array}$ \\
\hline Tenth Child & $\begin{array}{l}-.98 * \\
(.111)\end{array}$ & & & & & & & & & $\begin{array}{c}-1.919 * \\
(.399)\end{array}$ \\
\hline $\mathrm{N}$ & $1,427,107$ & 478,955 & 449,797 & 227,688 & 92,223 & 36,645 & 14,412 & 6,074 & 2,878 & 2,435 \\
\hline
\end{tabular}

* indicates statistical significance at the 5\% level. Standard errors (in parentheses) allow for correlation of errors within family. Each column represents a

separate regression. All regressions include indicators for age, mother's age, mother's education, father's education, father's age, and sex.

1 In this specification, indicator variables for family size are also included in the regression. 
Table 9: Effect of Birth Order on Children's Education

Estimated by Family Size

Family Fixed Effects

\begin{tabular}{|c|c|c|c|c|c|c|c|c|c|c|}
\hline & $\begin{array}{c}\text { All } \\
\text { Families }\end{array}$ & $\begin{array}{c}\text { Two } \\
\text { Child } \\
\text { Family }\end{array}$ & $\begin{array}{c}\text { Three } \\
\text { Child } \\
\text { Family }\end{array}$ & $\begin{array}{c}\text { Four } \\
\text { Child } \\
\text { Family } \\
\end{array}$ & $\begin{array}{c}\text { Five } \\
\text { Child } \\
\text { Family }\end{array}$ & $\begin{array}{c}\text { Six } \\
\text { Child } \\
\text { Family }\end{array}$ & $\begin{array}{c}\text { Seven } \\
\text { Child } \\
\text { Family }\end{array}$ & $\begin{array}{c}\text { Eight } \\
\text { Child } \\
\text { Family }\end{array}$ & $\begin{array}{c}\text { Nine } \\
\text { Child } \\
\text { Family }\end{array}$ & $\begin{array}{c}\text { Ten } \\
\text { Child } \\
\text { Family }\end{array}$ \\
\hline Second Child & $\begin{array}{l}-.340 \\
(.005)\end{array}$ & $\begin{array}{l}-.415^{*} \\
(.011)\end{array}$ & $\begin{array}{l}-.315^{*} \\
(.009)\end{array}$ & $\begin{array}{l}-.314^{*} \\
(.012)\end{array}$ & $\begin{array}{c}-.265^{*} \\
(.021)\end{array}$ & $\begin{array}{l}-.229 * \\
(.034)\end{array}$ & $\begin{array}{l}-.222 * \\
(.059)\end{array}$ & $\begin{array}{l}-.462 * \\
(.096)\end{array}$ & $\begin{array}{l}-.280 \\
(.151)\end{array}$ & $\begin{array}{c}-.366^{*} \\
(.170)\end{array}$ \\
\hline Third Child & $\begin{array}{l}-.531 \\
(.009)\end{array}$ & & $\begin{array}{l}-.599 * \\
(.017)\end{array}$ & $\begin{array}{l}-.523^{*} \\
(.018)\end{array}$ & $\begin{array}{l}-.460^{*} \\
(.027)\end{array}$ & $\begin{array}{l}-.449 * \\
(.042)\end{array}$ & $\begin{array}{l}-.404^{*} \\
(.070)\end{array}$ & $\begin{array}{l}-.672 * \\
(.111)\end{array}$ & $\begin{array}{l}-.593^{*} \\
(.172)\end{array}$ & $\begin{array}{c}-.666^{*} \\
(.188)\end{array}$ \\
\hline Fourth Child & $\begin{array}{l}-.611 \\
(.014)\end{array}$ & & & $\begin{array}{l}-.705^{*} \\
(.028)\end{array}$ & $\begin{array}{l}-.595^{*} \\
(.036)\end{array}$ & $\begin{array}{l}-.592 * \\
(.054)\end{array}$ & $\begin{array}{l}-.533^{*} \\
(.086)\end{array}$ & $\begin{array}{l}-.772 * \\
(.135)\end{array}$ & $\begin{array}{l}-.498^{*} \\
(.203)\end{array}$ & $\begin{array}{l}-.918^{*} \\
(.214)\end{array}$ \\
\hline Fifth Child & $\begin{array}{l}-.641 \\
(.020)\end{array}$ & & & & $\begin{array}{l}-.739 * \\
(.051)\end{array}$ & $\begin{array}{l}-.611^{*} \\
(.069)\end{array}$ & $\begin{array}{c}-.569^{*} \\
(.107)\end{array}$ & $\begin{array}{l}-.931 * \\
(.164)\end{array}$ & $\begin{array}{l}-.696^{*} \\
(.242)\end{array}$ & $\begin{array}{c}-.967^{*} \\
(.246)\end{array}$ \\
\hline Sixth Child & $\begin{array}{l}-.659 \\
(.028)\end{array}$ & & & & & $\begin{array}{l}-.747 * \\
(.090)\end{array}$ & $\begin{array}{l}-.604^{*} \\
(.132)\end{array}$ & $\begin{array}{l}-.923 * \\
(.197)\end{array}$ & $\begin{array}{l}-.686^{*} \\
(.286)\end{array}$ & $\begin{array}{c}-1.081 * \\
(.284)\end{array}$ \\
\hline Seventh Child & $\begin{array}{l}-.704 \\
(.042)\end{array}$ & & & & & & $\begin{array}{c}-.664^{*} \\
(.164)\end{array}$ & $\begin{array}{c}-1.140^{*} \\
(.237)\end{array}$ & $\begin{array}{l}-.791 * \\
(.339)\end{array}$ & $\begin{array}{c}-1.293 * \\
(.328)\end{array}$ \\
\hline Eighth Child & $\begin{array}{l}-.606 \\
(.062)\end{array}$ & & & & & & & $\begin{array}{c}-1.130^{*} \\
(.286)\end{array}$ & $\begin{array}{l}-.612 \\
(.396)\end{array}$ & $\begin{array}{c}-1.532 * \\
(.368)\end{array}$ \\
\hline Ninth Child & $\begin{array}{l}-.807 \\
(.094)\end{array}$ & & & & & & & & $\begin{array}{l}-.998 * \\
(.472)\end{array}$ & $\begin{array}{c}-1.647^{*} \\
(.416)\end{array}$ \\
\hline Tenth Child & $\begin{array}{l}-.940 \\
(.118)\end{array}$ & & & & & & & & & $\begin{array}{c}-1.982 * \\
(.483)\end{array}$ \\
\hline $\mathrm{N}$ & $1,427,107$ & 478,955 & 449,797 & 227,688 & 92,223 & 36,645 & 14,412 & 6,074 & 2,878 & 2,435 \\
\hline
\end{tabular}


Table 10

Specification Tests

Family Size and Birth Order Effects

Male/Female and Different Points of Distribution

\begin{tabular}{|c|c|c|c|c|c|}
\hline & $\begin{array}{c}\text { Male } \\
\text { (1) }\end{array}$ & $\begin{array}{c}\text { Female } \\
\text { (2) }\end{array}$ & $\begin{array}{c}\text { Prob } 12 \text { or More } \\
\text { Years of } \\
\text { Education } \\
\text { (3) }\end{array}$ & $\begin{array}{c}\text { Prob } 13 \text { or More } \\
\text { Years of } \\
\text { Education } \\
\text { (4) }\end{array}$ & $\begin{array}{l}\text { Prob } 16 \text { or } \\
\text { More Years of } \\
\text { Education } \\
(5)\end{array}$ \\
\hline \multicolumn{6}{|c|}{ Family Size } \\
\hline OLS & $\begin{array}{r}-.093^{*} \\
(.002)\end{array}$ & $\begin{array}{r}-.095^{*} \\
(.002)\end{array}$ & $\begin{array}{r}-.0186^{*} \\
(.0004)\end{array}$ & $\begin{aligned}-.0154^{*} \\
(.0003)\end{aligned}$ & $\begin{array}{l}-.0058^{*} \\
(.0002)\end{array}$ \\
\hline OLS with Birth Order & $-.025^{*}$ & .002 & $-.0038^{*}$ & -.0006 & $.0009 *$ \\
\hline Controls & $(.003)$ & $(.003)$ & $(.0004)$ & $(.0004)$ & $(.0003)$ \\
\hline IV - Twin at $2^{\text {nd }}$ Birth & $\begin{array}{l}.028 \\
(.066)\end{array}$ & $\begin{array}{l}.053 \\
(.068)\end{array}$ & $\begin{array}{l}.0069 \\
(.0093)\end{array}$ & $\begin{array}{l}.0069 \\
(.0093)\end{array}$ & $\begin{array}{l}.0042 \\
(.0072)\end{array}$ \\
\hline IV - Twin at $3^{\text {rd }}$ Birth & $\begin{array}{l}-.029 \\
(.061)\end{array}$ & $\begin{array}{l}-.001 \\
(.057)\end{array}$ & $\begin{array}{l}-.0055 \\
(.0087)\end{array}$ & $\begin{array}{l}-.0059 \\
(.0082)\end{array}$ & $\begin{array}{l}-.0019 \\
(.0060)\end{array}$ \\
\hline IV - Twin at $4^{\text {th }}$ Birth & $\begin{array}{l}-.074 \\
(.078)\end{array}$ & $\begin{array}{l}-.048 \\
(.079)\end{array}$ & $\begin{array}{l}-.0048 \\
(.0120)\end{array}$ & $\begin{array}{l}-.0042 \\
(.0104)\end{array}$ & $\begin{array}{l}-.0056 \\
(.0074)\end{array}$ \\
\hline \multicolumn{6}{|c|}{$\begin{array}{c}\text { Birth Order } \\
\text { Estimated with Family Fixed Effects }\end{array}$} \\
\hline Second Child & $\begin{array}{r}-.289 * \\
(.010)\end{array}$ & $\begin{array}{l}-.373^{*} \\
(.010)\end{array}$ & $\begin{array}{c}-.0543^{*} \\
(.0012)\end{array}$ & $\begin{array}{c}-.0525^{*} \\
(.0011)\end{array}$ & $\begin{array}{c}-.0307^{*} \\
(.0009)\end{array}$ \\
\hline Third Child & $\begin{array}{r}-.436^{*} \\
(.016)\end{array}$ & $\begin{array}{l}-.620^{*} \\
(.016)\end{array}$ & $\begin{array}{c}-.0884^{*} \\
(.0021)\end{array}$ & $\begin{array}{r}-.0812^{*} \\
(.0019)\end{array}$ & $\begin{array}{c}-.0465^{*} \\
(.0015)\end{array}$ \\
\hline Fourth Child & $\begin{array}{l}-.485^{*} \\
(.023)\end{array}$ & $\begin{array}{l}-.746^{*} \\
(.024)\end{array}$ & $\begin{array}{c}-.1053^{*} \\
(.0031)\end{array}$ & $\begin{array}{c}-.0980^{*} \\
(.0028)\end{array}$ & $\begin{array}{r}-.0524^{*} \\
(.0022)\end{array}$ \\
\hline Fifth Child & $\begin{array}{l}-.519^{*} \\
(.032)\end{array}$ & $\begin{array}{l}-.789^{*} \\
(.033)\end{array}$ & $\begin{array}{l}-.1166^{*} \\
(.0043)\end{array}$ & $\begin{array}{r}-.1064 * \\
(.0039)\end{array}$ & $\begin{array}{r}-.0559^{*} \\
(.0031)\end{array}$ \\
\hline Sixth Child & $\begin{array}{l}-.517^{*} \\
(.045)\end{array}$ & $\begin{array}{l}-.820^{*} \\
(.045)\end{array}$ & $\begin{array}{r}-.1323^{*} \\
(.0061)\end{array}$ & $\begin{array}{r}-.1173^{*} \\
(.0056)\end{array}$ & $\begin{array}{r}-.0570^{*} \\
(.0043)\end{array}$ \\
\hline Seventh Child & $\begin{array}{r}-.478^{*} \\
(.064)\end{array}$ & $\begin{array}{l}-.982^{*} \\
(.066)\end{array}$ & $\begin{array}{c}-.1493^{*} \\
(.0091)\end{array}$ & $\begin{array}{c}-.1288^{*} \\
(.0084)\end{array}$ & $\begin{array}{c}-.0580^{*} \\
(.0065)\end{array}$ \\
\hline Eighth Child & $\begin{array}{c}-.364^{*} \\
(.095)\end{array}$ & $\begin{array}{c}-.925^{*} \\
(.095)\end{array}$ & $\begin{array}{c}-.1328^{*} \\
(.0136)\end{array}$ & $\begin{array}{c}-.1164 * \\
(.0125)\end{array}$ & $\begin{array}{c}-.0500^{*} \\
(.0097)\end{array}$ \\
\hline Ninth Child & $\begin{array}{r}-.589^{*} \\
(.137)\end{array}$ & $\begin{array}{c}-1.062^{*} \\
(.146)\end{array}$ & $\begin{array}{l}-.1816^{*} \\
(.0207)\end{array}$ & $\begin{array}{c}-.1617^{*} \\
(.0191)\end{array}$ & $\begin{array}{c}-.0846^{*} \\
(.0147)\end{array}$ \\
\hline Tenth Child & $\begin{array}{l}-.810^{*} \\
(.177)\end{array}$ & $\begin{array}{c}-1.201 * \\
(.176)\end{array}$ & $\begin{array}{c}-.1903^{*} \\
(.0259)\end{array}$ & $\begin{array}{c}-.1720^{*} \\
(.0239)\end{array}$ & $\begin{array}{c}-.1039^{*} \\
(.0184)\end{array}$ \\
\hline
\end{tabular}

* indicates statistical significance at the $5 \%$ level. All family size regressions include indicators for age, mother's age, mother's education, father's education, and father's age. The third row presents the coefficient on family size for the first child for the sample of families with at least two children, using twins at second birth as an instrument; the fourth row is the effect of family size on the first two children conditional on having at least three children using twins at third birth as an instrument, and the fifth row is the effect of family size on the first three children conditional on having at least four children using twins at fourth birth as an instrument. Family size regressions in columns (3)-(5) also include a control for sex. The IV estimates include a full set of birth order controls. The Birth Order estimates come from family fixed effects specifications that include age indicators plus a sex indicator in columns (3)-(5). 
Table 11

Family Size and Birth Order Effects

By Mother's Education, Urban/Rural, and Cohort

\begin{tabular}{|c|c|c|c|c|c|c|}
\hline & $\begin{array}{c}\text { Mother's } \\
\text { Education } \\
\leq 12\end{array}$ & $\begin{array}{c}\text { Mother's } \\
\text { Education } \\
>12\end{array}$ & Urban & Rural & $\begin{array}{c}\text { Mother } \\
\text { Born } \\
\text { Before } 1935 \\
\end{array}$ & $\begin{array}{c}\text { Mother } \\
\text { Born After } \\
1935 \\
\end{array}$ \\
\hline \multicolumn{7}{|c|}{ Family Size } \\
\hline \multirow[t]{2}{*}{ OLS } & $-.100 *$ & $-.021 *$ & $-.094 *$ & $-.091 *$ & $-.083 *$ & $-.120 *$ \\
\hline & $(.002)$ & $(.007)$ & $(.004)$ & $(.002)$ & $(.003)$ & $(.003)$ \\
\hline \multirow[t]{2}{*}{ OLS with Birth Order } & $-.018 *$ & $.071 *$ & $.017^{*}$ & $-.014^{*}$ & $-.016^{*}$ & $-.011 *$ \\
\hline & $(.002)$ & $(.008)$ & $(.005)$ & $(.003)$ & $(.003)$ & $(.003)$ \\
\hline \multirow[t]{2}{*}{ IV - Twin at $2^{\text {nd }}$ Birth } & -.052 & -.089 & .039 & -.037 & .101 & -.011 \\
\hline & $(.051)$ & $(.122)$ & $(.080)$ & $(.058)$ & $(.078)$ & $(.058)$ \\
\hline \multirow[t]{2}{*}{ IV - Twin at $3^{\text {rd }}$ Birth } & -.034 & .086 & -.141 & .032 & .013 & -.045 \\
\hline & $(.047)$ & $(.121)$ & $(.077)$ & $(.053)$ & $(.070)$ & $(.054)$ \\
\hline \multirow[t]{2}{*}{ IV - Twin at $4^{\text {th }}$ Birth } & -.008 & -.143 & -.069 & .001 & -.060 & .029 \\
\hline & $(.062)$ & $(.206)$ & $(.122)$ & $(.068)$ & $(.086)$ & $(.078)$ \\
\hline \multicolumn{7}{|c|}{ Birth Order } \\
\hline \multicolumn{7}{|c|}{ Estimated with Family Fixed Effects } \\
\hline \multirow[t]{2}{*}{ Second Child } & $-.327 *$ & $-.289 *$ & $-.374 *$ & $-.322 *$ & $-.388^{*}$ & $-.305^{*}$ \\
\hline & $(.006)$ & $(.019)$ & $(.011)$ & $(.006)$ & $(.008)$ & $(.007)$ \\
\hline \multirow[t]{2}{*}{ Third Child } & $-.502 *$ & $-.516^{*}$ & $-.600^{*}$ & $-.508^{*}$ & $-.600 *$ & $-.475^{*}$ \\
\hline & $(.010)$ & $(.036)$ & $(.020)$ & $(.011)$ & $(.014)$ & $(.014)$ \\
\hline \multirow[t]{2}{*}{ Fourth Child } & $-.581 *$ & $-.611 *$ & $-.731 *$ & $-.592 *$ & $-.689 *$ & $-.548^{*}$ \\
\hline & $(.014)$ & $(.056)$ & $(.030)$ & $(.016)$ & $(.020)$ & $(.021)$ \\
\hline \multirow[t]{2}{*}{ Fifth Child } & $-.614^{*}$ & $-.651 *$ & $-.738^{*}$ & $-.643 *$ & $-.724 *$ & $-.578 *$ \\
\hline & $(.020)$ & $(.088)$ & $(.047)$ & $(.022)$ & $(.026)$ & $(.031)$ \\
\hline \multirow[t]{2}{*}{ Sixth Child } & $-.637 *$ & $-.663 *$ & $-.865^{*}$ & $-.659 *$ & $-.744 *$ & $-.603^{*}$ \\
\hline & $(.028)$ & $(.149)$ & $(.076)$ & $(.030)$ & $(.036)$ & $(.049)$ \\
\hline \multirow[t]{2}{*}{ Seventh Child } & $-.686^{*}$ & $-.857 *$ & $-.881 *$ & $-.723^{*}$ & $-.816^{*}$ & $-.587 *$ \\
\hline & $(.042)$ & $(.264)$ & $(.133)$ & $(.044)$ & $(.051)$ & $(.084)$ \\
\hline \multirow[t]{2}{*}{ Eighth Child } & $-.580^{*}$ & $-1.027^{*}$ & $-.902 *$ & $-.621^{*}$ & $-.709^{*}$ & $-.535^{*}$ \\
\hline & $(.062)$ & $(.395)$ & $(.209)$ & $(.065)$ & $(.074)$ & $(.135)$ \\
\hline \multirow[t]{2}{*}{ Ninth Child } & $-.795^{*}$ & -1.116 & $-1.058^{*}$ & $-.829 *$ & $-.919^{*}$ & $-.714^{*}$ \\
\hline & $(.094)$ & $(.702)$ & $(.304)$ & $(.099)$ & $(.110)$ & $(.226)$ \\
\hline \multirow[t]{2}{*}{ Tenth Child } & $-.917^{*}$ & $-2.357^{*}$ & -.479 & $-1.048^{*}$ & $-1.096^{*}$ & -.425 \\
\hline & $(.118)$ & $(.934)$ & $(.379)$ & $(.124)$ & $(.136)$ & $(.313)$ \\
\hline
\end{tabular}

* indicates statistical significance at the $5 \%$ level. All family size regressions include indicators for age, sex, mother's age, mother's education, father's education, and father's age. The third row presents the coefficient on family size for the first child for the sample of families with at least two children, using twins at second birth as an instrument; the fourth row is the effect of family size on the first two children conditional on having at least three children using twins at third birth as an instrument, and the fifth row is the effect of family size on the first three children conditional on having at least four children using twins at fourth birth as an instrument. The IV estimates include a full set of birth order controls. The Birth Order estimates come from family fixed effects specifications that include age indicators plus a sex indicator. 
Table A1

Average Spacing by Birth Order

\begin{tabular}{lccccc}
\hline Years Between Children & $\begin{array}{l}\text { 2 Child } \\
\text { Family }\end{array}$ & $\begin{array}{l}\text { 3 Child } \\
\text { Family }\end{array}$ & $\begin{array}{l}\text { 4 Child } \\
\text { Family }\end{array}$ & $\begin{array}{c}\text { 5 Child } \\
\text { Family }\end{array}$ & $\begin{array}{c}\text { 6 Child } \\
\text { Family }\end{array}$ \\
\hline First and Second Child & 4.0 & 3.0 & 2.5 & 2.3 & 2.1 \\
Second and Third Child & & 4.4 & 3.3 & 2.7 & 2.4 \\
Third and Fourth Child & & 4.3 & 3.2 & 2.6 \\
Fourth and Fifth Child & & & 4.0 & 3.0 \\
Fifth and Sixth Child & & & & 3.6 \\
\hline
\end{tabular}


Table A2: Effects of Birth Order on Children's Education

Estimated by Family Size Including Controls for Child Spacing and Family Fixed Effects

\begin{tabular}{|c|c|c|c|c|c|c|c|c|c|c|}
\hline & $\begin{array}{c}\text { All } \\
\text { Families }\end{array}$ & $\begin{array}{l}\text { Two Child } \\
\text { Family }\end{array}$ & $\begin{array}{c}\text { Three } \\
\text { Child } \\
\text { Family }\end{array}$ & $\begin{array}{c}\text { Four Child } \\
\text { Family }\end{array}$ & $\begin{array}{c}\text { Five } \\
\text { Child } \\
\text { Family }\end{array}$ & $\begin{array}{c}\text { Six } \\
\text { Child } \\
\text { Family }\end{array}$ & $\begin{array}{c}\text { Seven } \\
\text { Child } \\
\text { Family }\end{array}$ & $\begin{array}{c}\text { Eight } \\
\text { Child } \\
\text { Family }\end{array}$ & $\begin{array}{c}\text { Nine } \\
\text { Child } \\
\text { Family }\end{array}$ & $\begin{array}{c}\text { Ten } \\
\text { Child } \\
\text { Family }\end{array}$ \\
\hline Second Child & $\begin{array}{l}-.366 * \\
(.006)\end{array}$ & $\begin{array}{l}-.415^{*} \\
(.011)\end{array}$ & $\begin{array}{l}-.326^{*} \\
(.011)\end{array}$ & $\begin{array}{l}-.321 * \\
(.014)\end{array}$ & $\begin{array}{l}-.294 * \\
(.023)\end{array}$ & $\begin{array}{c}-.190 * \\
(.038)\end{array}$ & $\begin{array}{l}-.208 * \\
(.064)\end{array}$ & $\begin{array}{l}-.417^{*} \\
(.104)\end{array}$ & $\begin{array}{l}-.264 \\
(.162)\end{array}$ & $\begin{array}{l}-.250 \\
(.182)\end{array}$ \\
\hline Third Child & $\begin{array}{l}-.556 * \\
(.010)\end{array}$ & & $\begin{array}{l}-.593 * \\
(.017)\end{array}$ & $\begin{array}{l}-.532 * \\
(.020)\end{array}$ & $\begin{array}{l}-.495 * \\
(.030)\end{array}$ & $\begin{array}{c}-.384 * \\
(.049)\end{array}$ & $\begin{array}{l}-.393 * \\
(.080)\end{array}$ & $\begin{array}{l}-.614 * \\
(.131)\end{array}$ & $\begin{array}{l}-.579 * \\
(.199)\end{array}$ & $\begin{array}{l}-.484 * \\
(.220)\end{array}$ \\
\hline Fourth Child & $\begin{array}{l}-.626^{*} \\
(.014)\end{array}$ & & & $\begin{array}{l}-.706 * \\
(.029)\end{array}$ & $\begin{array}{l}-.614 * \\
(.038)\end{array}$ & $\begin{array}{c}-.528 * \\
(.059)\end{array}$ & $\begin{array}{l}-.525 * \\
(.097)\end{array}$ & $\begin{array}{l}-.702 * \\
(.157)\end{array}$ & $\begin{array}{l}-.455 \\
(.237)\end{array}$ & $\begin{array}{l}-.708 * \\
(.259)\end{array}$ \\
\hline Fifth Child & $\begin{array}{l}-.642 * \\
(.020)\end{array}$ & & & & $\begin{array}{l}-.724 * \\
(.051)\end{array}$ & $\begin{array}{l}-.572 * \\
(.071)\end{array}$ & $\begin{array}{l}-.568 * \\
(.113)\end{array}$ & $\begin{array}{l}-.871 * \\
(.181)\end{array}$ & $\begin{array}{l}-.644 * \\
(.273)\end{array}$ & $\begin{array}{l}-.738 * \\
(.298)\end{array}$ \\
\hline Sixth Child & $\begin{array}{l}-.651 * \\
(.028)\end{array}$ & & & & & $\begin{array}{l}-.750 * \\
(.091)\end{array}$ & $\begin{array}{l}-.607^{*} \\
(.134)\end{array}$ & $\begin{array}{l}-.864 * \\
(.207)\end{array}$ & $\begin{array}{l}-.648 * \\
(.306)\end{array}$ & $\begin{array}{l}-.856 * \\
(.332)\end{array}$ \\
\hline Seventh Child & $\begin{array}{l}-.690 * \\
(.042)\end{array}$ & & & & & & $\begin{array}{l}-.687 * \\
(.165)\end{array}$ & $\begin{array}{c}-1.094 * \\
(.240)\end{array}$ & $\begin{array}{l}-.777 * \\
(.352)\end{array}$ & $\begin{array}{r}-1.063 * \\
(.372)\end{array}$ \\
\hline Eighth Child & $\begin{array}{l}-.582 * \\
(.062)\end{array}$ & & & & & & & $\begin{array}{c}-1.103 * \\
(.287)\end{array}$ & $\begin{array}{l}-.624 \\
(.401)\end{array}$ & $\begin{array}{r}-1.304^{*} \\
(.405)\end{array}$ \\
\hline Ninth Child & $\begin{array}{l}-.778 * \\
(.094)\end{array}$ & & & & & & & & $\begin{array}{c}-1.033 * \\
(.474)\end{array}$ & $\begin{array}{r}-1.445^{*} \\
(.441)\end{array}$ \\
\hline Tenth Child & $\begin{array}{l}-.901 * \\
(.118)\end{array}$ & & & & & & & & & $\begin{array}{r}-1.838 * \\
(.498)\end{array}$ \\
\hline \# of children within 1 & $0.033 *$ & & $0.035^{*}$ & -0.003 & 0.030 & -0.001 & -0.013 & -0.002 & 0.007 & -0.099 \\
\hline year & $(0.008)$ & & $(0.015)$ & $(0.015)$ & $(0.018)$ & $(0.026)$ & $(0.038)$ & $(0.058)$ & $(0.084)$ & $(0.082)$ \\
\hline \# of children $2-3$ & $0.054 *$ & & $0.027 *$ & 0.009 & $0.035 *$ & $-0.052 *$ & -0.008 & -0.022 & 0.034 & -0.075 \\
\hline years & $(0.005)$ & & $(0.012)$ & $(0.011)$ & $(0.014)$ & $(0.020)$ & $(0.029)$ & $(0.044)$ & $(0.063)$ & $(0.059)$ \\
\hline $\begin{array}{l}\text { \# of children } 4-5 \\
\text { years }\end{array}$ & $\begin{array}{l}0.032 * \\
(0.005)\end{array}$ & & $\begin{array}{c}0.005 \\
(0.011)\end{array}$ & $\begin{array}{c}0.015 \\
(0.010)\end{array}$ & $\begin{array}{c}0.025 \\
(0.013)\end{array}$ & $\begin{array}{l}-0.037^{*} \\
(0.018)\end{array}$ & $\begin{array}{l}-0.007 \\
(0.028)\end{array}$ & $\begin{array}{l}-0.021 \\
(0.041)\end{array}$ & $\begin{array}{l}-0.085 \\
(0.058)\end{array}$ & $\begin{array}{l}-0.035 \\
(0.057)\end{array}$ \\
\hline $\mathrm{N}$ & $1,427,107$ & 478,955 & 449,797 & 227,688 & 92,223 & 36,645 & 14,412 & 6,074 & 2,878 & 2,435 \\
\hline
\end{tabular}

* indicates statistical significance at the 5\% level. Standard errors are in parentheses. Each column represents a separate regression. All regressions include indicators for age and sex. 
Table A3

Effect of Family Size on Children's Education Including Controls for Birth Order

Dependent Variable:

Child Education

Number of Children

Number of Children at Age 2

Number of Children at Age 5

Second Child

Third Child

Fourth Child

Fifth Child

Sixth Child

Seventh Child

Eighth Child

Ninth Child

Tenth Child

Family Fixed Effects?
(1)

(2)

$-.008^{*}$
$(.003)$
$-.024 *$
$(.005)$

$-.044 *$

$-.276^{*}$

(.005)

$-.457 *$

(.010)

$-.575^{*}$

(.015)

$-.642 *$

(.021)

$-.686^{*}$

(.030)

$-.739 *$

(.043)

$-.618 *$

(.065)

$-.790 *$

(.087)

$-.938 *$

(.122)

No

(.004)

(.119)

$-1.217^{*}$

(.083)

$-1.474 *$

No
(.003)

(3)

(4)

(5)

(6)

$-.043 *$

(.003)

$-.069^{*}$

(.005)

$.066 * \quad .091 *$

(.005)

$-.278 *$

(.005)

$-.469 *$

(.010)

$-.600^{*}$

(.015)

$-.680 *$

$(.021)$

$-.736 *$

(.030)

$-.803 *$

(.043)

$-.695 *$

(.065)

$-.878 *$

(.087)

$-1.054^{*}$

(.122)

(.122)

No

-.005
$(.006)$

$-.025^{*}$

(.006)

$.076^{*}$

(.006)

-.337*

(.006)

$-.525 *$

(.011)

$-.603 *$

(.016)

$-.628 *$

(.023)

$-.643 *$

(.032)

$-.686^{*}$

(.046)

$-.582 *$

(.067)

$-.779 *$

(.099)

$-.904 *$

(.124)

Yes

(.005)

$-.342 *$

$-.331 *$

(.005)

(.006)

$-.541 *$

$-.519^{*}$

(.009)

(.011)

-.639*

$-.604 *$

(.014)

(.016)

$-.691 *$

$-.641 *$

(.020)

(.023)

$-.737^{*}$

$-.673 *$

(.029)

(.032)

$-.820 *$

$-.740 *$

(.042)

(.046)

$-.756^{*}$

$-.661^{*}$

(.063)

(.067)

$-.995^{*}$

$-.883 *$

(.095)

(.099)

$-1.207^{*}$

$-1.065^{*}$

(.120)

(.124)

Yes

Yes

\begin{tabular}{lllllll}
\hline $\mathrm{N}=$ & $1,427,107$ & $1,427,107$ & $1,427,107$ & $1,427,107$ & $1,427,107$ & $1,427,107$ \\
\hline
\end{tabular}

* indicates statistical significance at the $5 \%$ level. Standard errors (in parentheses) allow for correlation of errors within family. All regressions include indicators for age, mother's age, and sex. Demographic controls, including indicators for mother's education, father's education, and father's age, are included in all regressions. 


\section{Twins Appendix: Validity of Twins Instrument}

In order for our IV estimates to be consistent, it must be that the instrument is uncorrelated with the error term in equation (3). One concern is that the occurrence of a twin birth may not be random and may be related to unobservable family background characteristics. By definition, this is untestable but we can examine whether the probability of twins is related to observed characteristics such as mother's and father's education. To do this, we estimated linear probability models of the probability of a twin birth at each parity using a full set of years of education indicators for mothers and fathers. F tests indicate that the hypothesis that the coefficients on mother's education are jointly zero and that the coefficients on father's education are jointly zero cannot be rejected at the $5 \%$ significance level (the $p$ value for mother's education is 0.45 in the regression for twin at second birth, 0.31 for twin at third birth, and 0.62 for twin at fourth birth; the analogous $\mathrm{p}$ values for father's education are $0.21,0.63$, and 0.51 respectively). Furthermore, when these variables are entered linearly as years of education, the coefficients are tiny and statistically insignificant. Given the enormous sample sizes, these results strongly suggest that twinning probabilities are not related to parents' education.

Although we include controls for year-of-birth of both mother and child (and hence implicitly, age of mother at birth controls), these relate to the age of the child under study and not to the age of the child from the potential twin birth. It is well-established that twin probabilities increase with maternal age at birth (Jacobsen, Pearce, and Rosenbloom, 1999; Bronars and Grogger, 1994), and a concern is that, because of the maternal age effect, twins are more likely to occur at a particular birth if the mother waits 
longer between that birth and the previous birth. If spacing has an independent effect on outcomes, this could bias results. We examine this issue by adding a measure of the gap between the child's birth and the potential twin birth into the linear probability model of the probability of a twin birth at each parity. As predicted by the maternal age effect, the coefficient on the gap is positive and statistically significant. For example, when considering the second birth, the coefficient implies that a gap of one extra year increases the probability of a twin by $0.0003 .{ }^{26}$ Similar size estimates are found for the probabilities of having twins at higher parities. These point estimates are very small and we have verified that adding a control for the gap preceding the potential twin birth in the 2SLS estimation has no appreciable effect on the family size estimates. Thus, both the parental education and spacing checks suggest that twinning is a fairly random event.

\section{Spacing and the Twins Instrument:}

Another concern is that the birth of twins changes not only the family size but also results in the closer spacing of children. As a result, twin births may effect the educational attainment of earlier children through mechanisms other than increasing family size. For example, in the case in which we use twins at second birth to study the outcomes of the first child, it may be that the first child is worse off if the second birth is a twin birth because he gets less attention if his siblings are more closely spaced. We have carried out some analysis to examine the extent to which this is a problem.

\footnotetext{
${ }^{26}$ This appears to be purely a maternal age effect -- we have verified that the positive relationship between the gap and probability of a twin birth goes away if controls are added for mother's age at birth at the time of the potential twin birth.
} 
The logic of our approach to test this is that, if spacing between children matters and more space is better for the existing child, then twins could be considered the extreme case with zero space. Though we cannot test for an effect of twins directly, we can determine whether spacing between children has an effect. If we find that shorter spaces are worse for the existing child, we can get an idea of how the extreme case (twins) might be affecting the existing child. Thus, we regress education of the first child on the age difference between the two following children, conditional on there being $\mathrm{X}$ children in the family. ${ }^{27}$ We estimate this regression for X equal to 3, 4, 5, and 6 . Likewise, we regress education of the first 2 children on the age difference between the $3^{\text {rd }}$ and $4^{\text {th }}$ child, also by family size $(4,5$, and 6$)$. We include the same set of control variables as earlier. The results are presented in Appendix Table 1. Note that, since spacing is endogenous and these are cross-sectional regressions, caution is required in interpreting these results.

We find that the coefficient on the distance between the two following siblings is generally positive and statistically significant. This implies that children do better if the two children immediately after them are spaced further apart. If, in the limit, this result can be extrapolated to the case of twins, in which the space is zero, it implies that the effect of a subsequent case of twins is both to increase family size and to adversely affect prior children through spacing. Thus, the 2SLS estimates of the effects of family size are probably biased towards finding negative effects of family size itself. Given that we find very small effects of family size using the twins instrument, this further strengthens the case that there is not a large negative effect of family size.

\footnotetext{
${ }^{27}$ We exclude families with twins from this analysis so that it is more likely that, for any given family size, spacing between two particular children is not systematically related to parental preferences for children.
} 


\section{Twins Appendix Table 1}

The Effects of Child Spacing on Previous Children's Outcomes

\begin{tabular}{lcccc}
\hline & & \multicolumn{2}{c}{ Family Size } \\
& F Child & 4 Child & 5 Child & 6 Child \\
& Family & Family & Family & Family \\
\hline Child 1 & $0.008^{*}$ & 0.005 & -0.008 & -0.021 \\
& $(0.002)$ & $(0.005)$ & $(0.011)$ & $(0.022)$ \\
Child 1 and 2 & & $0.019^{*}$ & $0.021^{*}$ & -0.002 \\
& & $(0.003)$ & $(0.007)$ & $(0.015)$ \\
Child 1, 2, 3 & & $0.021^{*}$ & $0.031^{*}$ \\
Child 1, 2, 3, & & $(0.004)$ & $(0.011)$ \\
& & & & $0.018^{*}$ \\
& & & & $(0.007)$ \\
\hline
\end{tabular}

* indicates statistical significance at the $5 \%$ level. Standard errors (in parentheses) allow for correlation of errors within family. Each cell represents a separate regression. All regressions include indicators for age, mother's age, mother's education, father's education, father's age, and sex.

The reported coefficients are those on the distance in years between the two children immediately after the children listed in column 1. For example, in row 1, the relevant variable is the distance between the second and third child; in row 2 the relevant variable is the distance between the third and fourth child. 